\title{
THE FREEDOM OF INFORMATION ACT IN 1990: MORE FREEDOM FOR THE GOVERNMENT; LESS INFORMATION FOR THE PUBLIC
}

\author{
SEAN E. ANDRUSSIER
}

\section{INTRODUCTION}

The Freedoin of Information Act (FOIA) was enacted in 1966 to provide American citizens with a inechanism to gani access to federal "agency records." 1 The essence of the FOIA is to require federal government agencies to disclose "agency records" upon request to "any person" requesting those records, subject to nine enumerated exemptions. ${ }^{2}$ Most of the hitigation arising under the FOIA involves the scope of the exemptions. In 1990, broad judicial construction of Supreme Court decisions and various FOIA exeinptions narrowed the reach of the FOIA's mandatory disclosure provisions, thereby curtailing the American public's ability to gain access to federal agency records. Additionally, in 1990 a inajority of federal agencies responding to a Department of Justice (DOJ) survey indicated that they oppose a general application of the FOIA to electronic records. In light of Congress's failure to annend the FOIA to include exphictly public access to such records, American citizens will contimue to encounter opposition when they attempt to gain access to electronic records.

Part II of this Note exanines the judicial developnients that occurred under the FOIA in 1990. Part II(A) examines the impact of the Supreine Court's 1989 landmark decision, Department of Justice v. Reporters Committee for Freedom of the Press, ${ }^{3}$ in the lower courts. This section argues that the lower courts are perhaps reading Reporters Committee too broadly, and in the process are unnecessarily curtailing public access to agency records. Part II(B) discusses the most significant decision rendered under the FOIA in 1990, New York Times Co. v. NASA, ${ }^{4}$ and its potential to substantially reduce access under FOIA Exemption

1. 5 U.S.C. $\S 552(1988)$.

2. See id. $\S \S(\mathrm{a})(3),(\mathrm{b})$.

3. 489 U.S. 749 (1989).

4. 920 F.2d 1002 (D.C. Cir. 1990) (en banc). 
6.5 Part II(C) discusses two decisions by the Court of Appeals for the District of Columbia Circuit that appear to frustrate Congressional intent by creating a virtual "irrebuttable" presumption in favor of the government under Exemption 7(D). ${ }^{6}$

Part III examines the results of a 1990 DOJ survey of seventy federal agencies regarding the apphication of the FOIA to agency records maintained in electronic form. This section notes the significance of the survey results in light of the absence of express language in the FOIA concerning the FOIA's application to electronic information. Part IV evaluates a bill passed by the House of Representatives in 1990 that would indirectly affect the FOIA im the context of electronic records by virtue of policies articulated in the accoinpanying report-policies favoring public access to electronic records. Additionally, the bill would directly ainend the FOIA by shifting administrative guidance of the FOIA from the DOJ to the Office of Managenient and Budget (OMB).

\section{Judicial DeVelopments}

\section{A. Categorical Non-Disclosure and Strict Public Interest: The Impact} of Department of Justice v. Reporters Committee for Freedom of the Press

Although the Supreme Court did not render any decisions under the FOIA in 1990, perhaps the dominant judicial thene in 1990 was the impact of the 1989 landmark Supreme Court decision, Department of Justice v. Reporters Committee for Freedom of the Press. ${ }^{7}$ The Court held, in determining the applicability of Exeinption $7(\mathrm{C}),{ }^{8}$ that the government may categorically deny FOIA requests for "rap sheets." In addition, the Court held that when requested records "can reasonably be expected to invade [a] citizen's privacy,"10 the records must shed light on the operations of the United States government to be subject to disclosure; the request cannot serve merely the interests of a particular requester. ${ }^{11}$

5. 5 U.S.C. $\S 552(b)(6)(1988)$.

6. $I d . \S 552(b)(7)(D)$.

7. 489 U.S. 749 (1989). For an in-depth discussion of Reporters Committee, see Note, Developments Under the Freedom of Information Act-1989, 1990 DUKE L.J. 1113, 1121-30 [hereinafter Developments-1989].

8. 5 U.S.C. $\$ 552(b)(7)(C)(1988)$.

9. Reporters Committee, 489 U.S. at 780. The D.C. Circuit defined "rap sheets" as "FBI records on individuals whose fingerprints have been submitted to the FBI in connection with arrests and, in certain instances, employinent, naturalization and military service. A rap sheet typically contains information concerning an individual's arrests, indictunents, convictions and imprisonments, and a notation of the source of the information." Reporters Comm. for Freedom of the Press v. Department of Justice, 816 F.2d 730, 732 n.2 (D.C. Cir. 1987) (citation omitted).

10. Reporters Committee, 489 U.S. at 780.

11. See id. at 775 . 
The Court's decision to categorically exempt rap sheets from the mandatory disclosure provisions is significant because by categorically exempting a certain type of information, that information cannot be disclosed regardless of its importance to a requester or to the general public. The Court's requirement that information with the potential to invade another's privacy must shed hight on government operations is equally significant, because not all requesters are able to demonstrate such a weighty public interest even though the requested information may be of extreme importance. Thus, Reporters Committee restricts access to agency records by making it easier for the government to withhold information.

Courts have indicated a tendency to interpret Reporters Committee broadly, applying the decision beyond rap shects and Exemption 7(C) to support and justify a broad construction of various FOIA exemptions. As a result, the public's ability to utilize the FOIA is substantially hampered. The impact of Reporters Committee is significant because, as the legislative history of the FOIA and the courts nake clear, FOIA exemptions should be construed narrowly to assure maximum disclosure of agency information. ${ }^{12}$

1. Department of Justice v. Reporters Committee for Freedom of the Press. Reporters Committee involved a dispute concerning the scope of FOIA Exemption 7(C). ${ }^{13}$ Exemption 7(C) permits agencies to withhold "rccords or information compiled for law enforcement purposes, but only to the extent that the production of such [materials] ... could reasonably be expected to constitute an unwarranted invasion of personal privacy . . ."14 Prior to Reporters Committee, courts that determined the applicability of Exemption 7(C) required simply an identification and subsequent balancing of the relevant privacy interests in nondisclosure with the public interest in gaining access to that information. This balancing was performed on a case-by-case basis to determine if disclosure "could reasonably be expected to constitute an unwarranted invasion of personal privacy." 15 If the public interest/privacy interest balance favored privacy (i.e., the public interest im gaining access to the information was not so important as to justify the personal privacy imvasion), then the government was not required to disclose requested agency records. Furthermore, if there was no public interest in accessing the

12. See, e.g., Department of the Air Force v. Rose, 425 U.S. 352, 361 (1976).

13. 5 U.S.C. $\S 552(b)(7)(C)(1988)$.

14. Id. Thus, Exemption 7(C) protects the privacy of individuals whose names or other personal information appears in a requested record.

15. See Lesar v. Department of Justice, 636 F.2d 472, 486 (D.C. Cir. 1980). 
information, even a less-than-substantial invasion of privacy would be deemed sufficient to prevent disclosure. ${ }^{16}$ The range of acceptable public interests to justify disclosure, however, was generally broad; many courts would consider the requester's alleged interest in the request (as opposed to soine larger, inore truly "public," interest). ${ }^{17}$

In Reporters Committee, the Court adopted two approaches that significantly altered the traditional Exeinption 7(C) calculus, thereby expanding the ability of the government to withhold agency records under the FOIA. First, the Court narrowed the scope of the public interest that will balance against alleged privacy interests. ${ }^{18}$ If an alleged public interest does not satisfy the Court's new standard, then it cannot be balanced against privacy interests; the invasion will be unjustified and the requested information may be withheld. If the public interest does satisfy the Court's standard, it may be balanced against the privacy interests to determine if disclosure is unwarranted.

Second, the Court utilized a categorical balancing approach, essentially by finding that the disclosure of rap sheets, by their very nature, would always constitute an unwarranted invasion of personal privacy under Exemption 7(C). ${ }^{19}$ In doing so, the Court stated in dicta that categorical decisions "may be appropriate" in certain circumstances. ${ }^{20}$ Lower courts have interpreted this language to justify categorical decisionmaking in certain circumstances not specifically authorized by the Court. Thus, those courts will not balance public and private interests in their disclosure determinations.

In formulating this departure froin traditional Exemption 7(C) analysis, the Court first concluded, not surprisingly, that the subjects of rap slieets have a substantial privacy interest in their criminal histories.21 Next, the Court considered whether the invasion of personal privacy would be unwarranted, ${ }^{22}$ announcing that "whether an invasion of privacy is warranted cannot turn on the purposes for which the request for information is inade." ${ }^{23}$ Thus, the identity of the requesting party is ir-

16. See King v. Department of Justice, 586 F. Supp. 286, 294 (D.D.C. 1983), aff'd, 830 F.2d 210 (D.C. Cir. 1987).

17. Cf. Ditlow v. Schultz, 517 F.2d 166, 172 (D.C. Cir. 1975) (in the context of Exception 6, public interest considerations cannot be limited to monitoring federal government).

18. See Department of Justice v. Reporters Comm. for Freedom of the Press, 489 U.S. 749, $772-75$ (1989).

19. See id. at $776-81$.

20. See id. at 776.

21. Id. at 771.

22. See 5 U.S.C. § 552(b)(7)(C) (1988).

23. Reporters Committee, 489 U.S. at 771. 
relevant to a determination of whether a court should grant a FOIA request. ${ }^{24}$

Instead, the Court posited a new; nore stringent public interest requirement by concluding that whether an invasion of privacy is warranted is contingent upon "the nature of the requested document and its relationship to 'the basic purpose of the Freedom of Information Act to open agency action to the light of public scrutiny." "25 Such a public interest standard, explained the Court, is consistent with the FOIA's policy to provide citizens with the right to be informed about "what their government is up to." 26

Having substantially narrowed the scope of the public interest required to refute an agency's Exemption 7(C) claim, the Court went one step further. Instead of simply permitting the government to withhold the rap sheets (since they would fail to shed hight on government operations), the Court adopted a categorical approach to dispose of rap sheet requests, stating that "categorical decisions may be appropriate and individual circumstances disregarded when a case fits into a genus in which the balance characteristically tips in one direction." 27 Consequently, the Court held:

24. Id.; cf. Schwaner v. Department of the Air Force, 898 F.2d 793, 798 (D.C. Cir. 1990) (Exemption 2 case holding requester identity irrelevant to court's decision to order (as opposed to deny) disclosure-depsite the fact that requester was an insurance agent requesting personnel names and addresses as a source for future commissions).

25. Reporters Committee, 489 U.S. at 772 (quoting Department of the Air Force v. Rose, 425 U.S. 352, 372 (1976)) (emphasis added).

26. Id. at 773 (emphasis added). In light of the foregoing strict view of when an invasion of privacy may be warranted under Exemption $7(C)$, the Court rcasoned that in a typical case in which a person seeks information about another citizen, the requester does not want to learn anything about the conduct of the partieular agency that possesses the requested records and a "response to this request would not shed any light on the conduct of any Government agency or official." Id. Consequently, although the rap sheet information requested by certain members of the media in Reporters Committee might be "newsworthy," newsworthiness alone is an insufficient public interest. It does not ensure that the government is subject to scrutiny. See id. at $\mathbf{7 7 4}$.

The Court recognized that if the requesters in Reporters Committee were entitled to the personal information in the rap sheets, then anyone, for whatever reason, also would be entitled to the information. Id. at 775. This rule stems from the language of the FOIA, which states that "each agency upon any request for records ... shall make the records promptly available to any person." 5 U.S.C. $\S 552(\mathrm{a})(3)$ (1988) (emphasis added). For a discussion of how courts have utilized the "any person" standard both to increase and to restrict information dissemination under the FOIA, see The 'Any Person' Standard: A Double Edged Sword, ACCEss REP., Feb. 7, 1990, at 4, 6 (although the "any person" language was placed in the FOIA to ensure use of the FOIA by anyone, cases such as Reporters Committee cite the "any person" language to support the restriction of dissemination by adopting worst-case scenarios of who could receive such information).

27. Reporters Committee, 489 U.S. at 776. The Court of Appeals was concerned about a judge balancing individual privacy interests and public interests in the disclosure of rap sheet information on a case-by-case-basis. See id. This is an interesting concern, because judges balance such competing interests all the time. 
[A]s a categorical matter . . . a third party's request for law enforcement records or information about a private citizen can reasonably be expected to invade that citizen's privacy, and ... when the request secks no "official information" about a Government agency, but merely records that the Government happens to be storing, the invasion of privacy is "unwarranted."28

Thus, after Reporters Committee, no ad hoc balancing is required when a request involves another person's rap sheet; such records are categorically exempt from disclosure.

A survey of the decisions rendered under the FOIA in 1990 deinonstrates that courts have interpreted and applied Reporters Committee to broaden the scope of Exemption 7(C) and other FOIA exeinptions, thereby curtailing disclosure. This broadening has been achieved under the two approaches posited in Reporters Committee: a strict public interest requireinent, and the Court's use of categorical decisioninaking.

\section{Categorical balancing: Narrowly applied or broadly authorized?} Although the Court utilized categorical balancing in Reporters Committee, it is unclear whether it intended to authorize that approach in the lower courts or whether the analysis was limited to the facts presented in that case-requests for the criminal history of another person. The use of the categorical approach is controversial because it precludes the caseby-case review that Congress intended when drafting the FOIA, with its goal of mandatory disclosure. ${ }^{29}$ Nonetheless, lower courts have interpreted the Court's holding broadly, and have extended the categorical approach beyond the facts underlying Reporters Committee.

Landano v. Department of Justice ${ }^{30}$ is an example of a lower court's broad interpretation and apphication of Reporters Committee. Landano involved a FOIA suit to coinpel the FBI to release information regarding an FBI mvestigation into the murder of a police officer. ${ }^{31}$ Plaintiff, who

28. Id. at 780 .

29. The legislative history of the original enactment of the FOIA implies an intent for case-bycase review, which is arguably circumvented by categorical decisionmaking. Cf. CLARIFYING AND Protecting the Right of the Public to Information, and for Other PuRposes, S. Rep. No. 813, 89th Cong., 1st Sess. 3 (1965) ("It is not an easy task to balance the opposing interests [of freedom of information and rights of privacy], but it is not an inpossible task either.... Success lies in providing a workable formula which encompasses, balances, and protects all interests, yet places emphasis on the fullest possible disclosure.") (einphases added); id. ("It is the purpose of [the FOIA] ... to establish a general philosophy of full agency disclosure unless information is exempted under clearly delineated statutory language ....") (emphasis added); CLARIFYING AND PROTECTING THE Right of the Public to Information, H.R. Rep. No. 1497, 89th Cong., 2nd Sess. 9 (1966) ("The [appeal] proceedings [in the federal courts] are to be de novo so that the court can consider the propriety of withholding ....").

30. 651 F. Supp. 502 (D.N.J. 1990).

31. Id. at 504. 
was convicted of felony murder as a result of the investigation, maintained that the requested files contained information that proved his innocence of murder, and that such information was withheld from him and his counsel during his trial. ${ }^{32}$ Relying on Exemption 7(C), the FBI withheld the names of FBI special agents, FBI support employees, police officers, and other third parties involved in the murder investigation, including witnesses. ${ }^{33}$

In determining whether the government was justified in withholding the requested information under Exemption $7(C),{ }^{34}$ the United States District Court for the District of New Jersey ${ }^{35}$ immediately referred to Reporters Committee, stating:

[C]ertain types of information may, as a matter of law, be withheld from an applicant under what the Supreme Court has called "categorical balancing." In Reporters Committee, the Supreme Court sanctioned the practice of categorical balancing under exemption 7(C) and other exemptions while holding that all rap sheet information not requested by its subject is exempt from FOIA disclosure under exemption $7(\mathrm{C}) .^{36}$

Consequently, the Landano court concluded that Reporters Committee's acceptance of categorical withholding "compelled" it to exempt categorically the names of informants and undercover agents. ${ }^{37}$

Reporters Committee, however, did not categorically exempt the names of informants or undercover agents froin disclosure. In Reporters Committee, the Court was confronted with a somewhat narrow FOIA request for the criminal history of a third-party private citizen. Although the Court was dealing generally with a rap sheet, what the plaintiff requested and what the Court found to be highly sensitive (in terms of its inherent privacy implications) was information about the subject of the requested rap sheet. Thus, it is arguable that, in light of the sensitive nature of the request before the Court, the holding of Reporters Committee should be interpreted narrowly: Courts may categorically exempt criminal history information about the subjects of rap sheets. ${ }^{38}$

32. Id. 13 years had elapsed between the time of plaintiff's conviction and the FOIA suit.

33. Id. at 506.

34. 5 U.S.C. $\S 552(b)(7)(C)(1988)$.

35. The FOIA provides that federal district courts have "jurisdiction to enjoin the agency from withholding agency records and to order the production of any agency records improperly withheld ..." Id. $\S 552(\mathrm{a})(4)(\mathrm{B})$.

36. Landano, 751 F. Supp. at 506 (emphasis added).

37. Id. at 507 .

38. The Supreme Court's opinion seemed to emphasize the nature of rap sheets and the potential danage caused by their disclosure. The Court did not hold that a categorical analysis should be used as often as possible to prevent, or efficiently adjudicate, FOIA disputes. The Court's statement that "categorical decisions may be appropriate," Department of Justice v. Reporters Comm. for Freedom of the Press, 489 U.S. 749, 776 (1989), was purely dictum. 
Landano, however, did not limit its categorical analysis to the withholding of individual criminal history information about the subject of a rap sheet. Rather, the court expanded Reporters Committee by adding the naines of FBI informants and undercover agents involved in an investigation to the list of categories of information exempt under Exemption $7(C){ }^{39}$ Although its apphication to the facts of Landano may not seem offensive, other courts could potentially create an unlinited list of types of information that would never be accessible to the public. This would, of course, run counter to the goal of the FOIA-inaximuin access-and to Congress's intent to carve out a limited set of exemptions from that pohicy.

Nevertheless, Landano's expansion of Reporters Committee is arguably justified in hight of the Suprene Court's general pronouncement that "categorical decisions nay be appropriate ... when a case fits into a genus in which the balance characteristically tips in one direction." $40 \mathrm{By}$ failing to specify which information should be categorically exeinpt, this language can be read, as the Landano court read it, to authorize courts to balance categorically at their discretion. ${ }^{41}$ The Supreme Court did not, however, expressly compel or authorize categorical balancing under

Indeed, support for a narrow interpretation of the Court's holding in Reporters Committee can be implied from the concurring opinion of Justice Blackmun. He stated that "the Court's use of 'categorical balancing' under Exemption 7(C) ... [was] not basically sound." Id. at 780-81 (Blackmun, J., concurring in the judgment). Further, Justice Blackmun questioned whether the use of categorical balancing would "run aground on occasion, such as in a situation where a rap sheet discloses a congressional candidate's conviction of tax fraud ...." Id.

Justice Blackmun's opinion indicates that he believed that the majority's categorical analysis was limited to the facts of Reporters Committee. It is arguable that if Justice Blackmun believed that the majority was compelling or authorizing widespread categorical balancing, he surely would have articulated a broader criticism than one aimed at the majority's use of categorical balancing for rap sheets; he would not have simply focused on those situations in which disclosure of rap sheet information may be appropriate. If Justice Blackmun was troubled with the use of categorical balancing in such an uncontroversial setting such as rap sheet requests, he probably would have been deeply concerned with an authorization beyond the facts of Reporters Committee.

39. Landano, 751 F. Supp. at 509.

40. Reporters Committee, 489 U.S. at 776.

41. Indeed, the Landano court believed that the Court's categorical balancing guidelines compelled the court to exempt the information, and that "the Supreme Court sanctioned the practice of categorical balancing under Exemption 7(C) and other exemptions." 751 F. Supp. at 506 (emphases added). 
7(C). ${ }^{42}$ Nevertheless, Reporters Committee's categorical balancing approach has surfaced even under Exeinptions $6^{43}$ and 7(D). ${ }^{44}$

3. The scope of the public interest requirement after Reporters Coinmittee. Reporters Committee also limited the range of public interests that a court can consider when determining the merit of agency withholding under Exeinption 7(C). The Court held that when balancing under Exeinption 7(C) the alleged public interest in accessing the requested information against the potential invasion of personal privacy that would occur if the information were disclosed, the only public interest that shonld enter the equation is one that would shed light on government operations. This new public interest requireinent has significantly restricted the disclosure of information under Exemption 7(C).

Arguably, the reasoning and holding of Reporters Committee concerning what constitutes a valid public interest for purposes of gaining access to agency information should be limited to Exemption 7(C) analyses. In other words, plaintiffs making FOIA requests, in general, should not have to demonstrate that the information they request will shed hight on governinent operations. Several courts, however, have deinonstrated a willingness to stretch the heightened public interest requirement beyond Exemption $7(\mathrm{C}) .45$

The argument that Reporters Committee's stringent public interest standard should only be required under Exeinption 7(C) begins with a recoguition that courts have consistently imterpreted Exemption 7(C) (as opposed to other exemptions) in favor of the government. ${ }^{46}$ Indeed, the Supreme Court has construed Exeinption 7(C) broadly. ${ }^{47}$ The legislative

42. Furthermore, if a court intends to exeinpt categorically certain information, that court should, as the Court did in Reporters Committee, demonstrate that in all instances the public interest would be invalid. Not only does Landano fail to demonstrate this, but the court fails to mention whether there was, or could be, a specific public interest in obtaining the names of informants or undercover agents.

43. See infra notes 151-52 and accompanying text (discussing New York Tiines Co. v. NASA, 920 F.2d 1002 (D.C. Cir. 1990) (en banc)).

44. See infra notes $182-91$ and accompanying text and note 193 (discussing Dow Jones \& Co. v. Department of Justice, 917 F.2d 333 (D.C. Cir. 1990)).

45. See infra note 54 and notes 63-64 and accompanying text (applying standard under Exemption 6); see also infra notes 84-86 and accoinpanying text (Judge Revercomb suggesting that the lieightened public interest standard should be applied under Exemption 2).

46. See, e.g., Senate of Puerto Rico v. Department of Justice, 823 F.2d 574, 587 (D.C. Cir. 1987 ) (unlike other FOIA exemptions, "Exemption 7(C)'s balance is not similarly 'tilted in favor of disclosure." " (quoting Bast v. Department of Justice, 665 F.2d 1251, 1254 (D.C. Cir. 1981))).

47. See Harvey v. Department of Jnstice, 747 F. Supp. 29, 40 (D.D.C. 1990) ("The Supreme Court takes a liberal view of what constitutes an 'unwarranted invasion of personal privacy' witlin tlie meaning of Exemption 7(C)."). 
history of Exemption $7(C)$ provides additional support for this interpretation.

After Congress amended the FOIA in 1974,48 Exemption 7(C) was triggered when disclosure of law enforcement records "would . . constitute an unwarranted invasion of personal privacy." 49 Congress exphicitly omitted the adverb "clearly" that modifies the phrase "unwarranted invasion of privacy" in Exemption 6.50 In 1986, Exemption 7(C) was again amended, with Congress substituting "could reasonably be expected to" for "would" as the standard for reviewing the risk of harm from disclosure. ${ }^{51}$ The 1974 and 1986 amendments to Exemption 7(C)'s language imply a congressional imtent that Exemption 7(C) should be broadly read to safeguard against potential imvasions of personal privacy inherent in the disclosure of law enforcement records. ${ }^{52}$

In sum, Exemption $7(C)$ should be broadly read. Consequently, when the Court announced in Reporters Committee that requesters who attempt to defeat an agency's Exemption 7(C) claim must have an interest in "what the government is up to," it is arguable that the Court expected such a public interest requirement to be limited to Exemption 7(C) challenges, because disclosure of information contained in law enforcement records can be particularly damaging.

a. Requiring a requester to have an interest in government operations when challenging agency withholding under Exemption $6 . \quad$ Requiring a FOIA plaintiff who requests law enforceinent records to demonstrate that the requested information will shed hight on govern-

48. The FOIA, enacted in 1966, has been amended several times since its inception (1967, 1974, 1976, 1978, 1984, and 1986). Act of June 5, 1967, Pub. L. No. 90-23, § 1, 81 Stat. 54; Act of Nov. 21, 1974, Pub. L. No. 93-502, $\S \S 1-3,88$ Stat. 1561-64; Act of Sept. 13, 1976, Pub. L. No. 94-409, $\S 5(b), 90$ Stat. 1247; Act of Oct. 13, 1978, Pub. L. No. 95-454, § 906(a)(10), 92 Stat. 1225; Act of Nov. 8, 1984, Pub. L. No. 98-620, § 402(2), 98 Stat. 3357; Act of Oct. 27, 1986, Pub. L. No. 99-570, $\S \S 1802,1803,100$ Stat. 3207-48, 3207-49.

49. Act of Nov. 21, 1974, Pub. L. No. 93-502, 88 Stat. 1561, 1563. Before the 1974 amendment, Exemption 7 excluded "mvestigatory files compiled for law enforcement purposes except to the extent available by law to a party other than an agency." Act of June 5, 1967, Pub. L. No. 90-23, 81 Stat. $54,55$.

50. See Department of Justice v. Reporters Comm. for Freedom of the Press, 489 U.S. 749, 756 n.8 (1989) (citimg 120 CoNG. REC. 33158-59 and 34162-63 (1974)) (noting that the word "clearly" was omitted in response to the President's concerns).

51. Freedom of Information Reform Act of 1986, Pub. L. No. 99-570, 100 Stat. 3207-48.

52. Relatedly, a broad construction of Exemption $7(C)$ is supported by a comparison to the language of Exemption 6-also a personal privacy exemption-which protects personnel, medical, and "similar files." 5 U.S.C. $\$ 552(b)(6)(1988)$. Exemption $7(C)$ explicitly imports a less stringent standard for the government to satisfy in order to deny a FOIA request. Under Exemption 6, agencies must prove that the requested information would constitute a clearly unwarranted invasion of privacy, whereas Exemption $7(\mathrm{C})$ requires merely a showing that disclosure could reasonably be expected to constitute an unwarranted invasion of privacy. 
ment operations is consistent with the liberal view of Exemption 7(C), and is evidently endorsed by Congress. ${ }^{53}$ However, it is questionable whether plaintiffs need to demonstrate that requested information will shed hight on the operations of the government when the government withholds information under other FOIA exemptions. The D.C. Circuit answered that question in the affirmative in $1989 ;{ }^{54}$ in 1990 the Court of Appeals for the Eleventh Circuit, in Ray v. Department of Justice, ${ }^{55}$ agreed, applying Reporters Committee's heightened public interest requirement under Exemption 6. That conclusion, however, does not necessarily follow from Reporters Committee. Moreover, that result makes it more difficult for citizens to gain access to records the government deems to be "personnel and medical files and similar files," records exempted by Exemption 6.

In Ray, Haitians who sought political asylum requested information from government agencies regarding Haitian nationals who had been returned to Haiti. ${ }^{57}$ Specifically, plaintiffs requested information concerning how the Haitian government treated its citizens who were returned to Haiti after unsuccessfully attempting to flee to the Umited States. ${ }^{58}$ The Eleventh Circuit affirmed the lower court's finding that the requested imformation, which consisted of names, addresses, and other identifying information, was not covered by Exemption 6, and therefore must be disclosed. ${ }^{59}$ In reaching that conclusion, however, the court implicated the Reporters Committee public imterest requirement under Exemption 6.

The Eleventh Circuit's opimion in Ray began by applying the traditional Exemption 6 balancing test, " 'weighing an individual's right to protection of privacy against the public's right to disclosure of govern-

53. See supra notes $46-52$ and accompanying text.

54. See National Ass'n of Retired Fed. Employees v. Horner, 879 F.2d 873 (D.C. Cir. 1989). In Horner, an Exemption 6 case, the court stated that "unless the public would learn something directly about the workings of the Government ... disclosure is not affected with the public interest." Id. at 879. The court rejected two asserted public interests in receiving the names and addresses of federal annuitants. First, the court rejected the assertion that there was a public interest in the petitioner receiving the information for lobbying purposes. Second, the court found no public interest in informing the public low its money was being spent. Id; see also Federal Labor Relations Autl. v. Department of the Treasury, 884 F.2d 1446, 1451-52 (D.C. Cir. 1989) (applying Reporters Committee's heightened public interest standard under Exemption 6).

55. 908 F.2d 1549 (11tli Cir. 1990).

56. 5 U.S.C. $\S 552(b)(6)(1988)$.

57. Ray, 908 F.2d at 1552.

58. Id. The plaintiffs sought evidence to support tlieir contention that the Haitian government would persecute them if they were returned to Haiti and that, consequently, they deserved political asylum. Id.

59. Id. at 1553. 
ment information." "60. The court first noted that significant privacy interests were at stake because the U.S. government had promised the returned Haitians confidentiality, and because the plaintiffs intended to contact the returned Haitian individuals whose names were being withheld. ${ }^{61}$ After reviewing the public interest in the request, however, the court held that the public interest in obtaining the information outweighed the privacy interest and ordered disclosure. ${ }^{62}$

Ray looked to Reporters Committee to guide its finding that the asserted public interest was sufficient, stating: "We recognize that the Supreme Court has made clear that the FOIA's basic purpose is to provide the public with a means of learning what its government is up to; the Act is not desigued to assist citizens in gaining information about other individuals for private purposes." 63 Thus, the court agreed with the government that to the extent that the plaintiffs' FOIA request was motivated by self-interest (i.e., not being deported), such an objective was not the sort of goal the FOIA was enacted to serve.64 The court did, however, find a valid public interest: ascertaining whether the U.S. government was "momtoring Haiti's compliance with its obligation not to persecute returnees and to learn whether [the U.S.] governinent [was] honest to the public about Haiti's treatment of returnees."65

Although the Eleventh Circuit found a valid public interest, it is questionable whether courts should apply the Reporters Committee pubhic interest requirement under Exemption 6. As noted in Ray, Reporters Committee did not address the application of Exeinption 6.66 Exemption 6 , by its terins, provides a higher burden for the government to satisfy in order to withhold requested information: Exemption 6 requires a demonstration that disclosure "would constitute a clearly unwarranted invasion of personal privacy"; whereas Exeinption 7(C) permits governinent withholding of information that "could reasonably be expected to consti-

60. Id. at 1554 (quoting Cochran v. United States, 770 F.2d 949, 955 (11th Cir. 1985)). Exemption 6, hike Exemption 7, ordinarily involves balancing the public interest in disclosure against the degree of the invasion of privacy that would result from diselosure. See Lesar v. Department of Justice, 636 F.2d 472, 486 n.80 (D.C. Cir. 1980).

61. Ray, 908 F.2d at 1554 .

62. Id.

63. Id.

64. Id. at 1555.

65. Id. See infra note 91 and accompanying text (evaluating the asserted public interest in Ray).

66. Ray, 908 F.2d at 1555 n.2. See also Painting Indus. Mkt. Recovery Fund v. Department of the Air Force, 751 F. Supp. 1410, 1416 n.3 (D. Haw. 1990) ("Although Reporters Committee is a landmark case in the area of analysis of FOIA exemptions implicating privacy rights, the deeision dealt with the 7(C) Exemption and not Exemption 6. Accordingly, Reporters Committee is cautiously applied to an analysis of Exemption $6 \ldots .$. "). 
tute an unwarranted invasion of personal privacy." 67 Despite the objections of several agency representatives who wanted Congress to remove the restrictive language, ${ }^{68}$ Congress maintained the current version of Exemption 6. The Supreme Court itself acknowledged in Reporters Committee that "the standard for evaluating a threatened invasion of privacy interests [under Exemption $7(C)$ ] is somewhat broader than the standard applicable to [Exemption 6]."69

In light of the legislative history and the obvious differences between the language chosen by Congress for each exemption, ${ }^{70}$ it is arguable that apphication of the Reporters Committee public interest requireinent should be limited only to those plaintiffs who challenge the governinent's withholding under Exemption 7(C). It is one thing to contend that the Court set a requirement (that requested information inust shed hight on government operations), the absence of which constitutes an unwarranted invasion of privacy triggering non-disclosure; however, it is quite another proposition to suggest that this absence satisfies Exemption 6's requirement of a "clearly" unwarranted invasion of privacy to prevent disclosure. ${ }^{71}$ The argument follows, then, that congressional, not judicial, action should broaden the scope of a narrow FOIA exemption. ${ }^{72}$

One can find support, however, for stretching the Reporters Committee public interest requirement to Exemption 6 . When discussing the

67. 5 U.S.C. $\$ 552(b)(6),(7)(C)(1988)$ (emphases added). Exemption 6 protects from public disclosure and dissemination "personnel and medical files and similar files," whereas Exemption $7(C)$ protects "records or information compiled for law enforcement purposes." Id. Although both Exemption 6 and $7(C)$ utilize a balancing approach, law enforcement records arguably have the potential to be more damaging than medical or personnel files. See Bast v. FBI, 665 F.2d 1251, 1254 (D.C. Cir. 1981); see also Branch v. FBI, 658 F. Supp. 204, 209 (D.D.C. 1989) ("It is generally recognized that the mention of an individual's name in a law enforcement file will engender comment and speculation and carries a stiginatizing connotation.").

68. See Developments-1989, supra note 7, at 1128 n.102 (citing Hearings on H.R. 5012 before a Subcomm. of the House Comm. on Government Operations, 89th Cong., 1st Sess. 56 (1965) (testimony of Fred B. Smith, acting General Counsel, Treasury Department); id. at 257 (testimony of William Feldesman, NLRB solicitor)).

69. Department of Justice v. Reporters Comm. for Freedom of the Press, 489 U.S. 749, 756 (1989). See generally id. at 756 \& n.9 (discussing legislative histories and differences between language of Exemptions 6 and $7(\mathrm{C})$ ).

70. See supra notes 49-52 and accompanying text.

71. If Reporters Committee had been decided under Exemption 6, then stretching the Court's standard to Exemption 7(C) would seem less offensive in that, if the absence of the standard would make an invasion of privacy "clearly" unwarranted, it would necessarily be implicated as making an invasion of privacy merely unwarranted.

72. See Developments-1989, supra note 7, at 1128-29:

In the future, Congress may decide that an added exemption may be necessary to prevent exploitation of the FOIA as a source of business information for private commercial interest. Until that occurs, however, it is not within a court's province to expand exemptions in order to narrow the statute and thereby subvert the public's congressionally created right to information. 
public interest requirement under 7(C), Reporters Committee drew support froin Department of the Air Force v. Rose, ${ }^{73}$ an earlier Exeinption 6 case. ${ }^{74}$ Rose noted that "the basic purpose of the [FOIA is] 'to open agency action to tlie liglit of public scrutiny." "75 Reporters Committee, commenting on Rose, explained that "[i]f, instead of seeking information about the [Air Force] Academy's own conduct, the requests liad asked for specific files to obtain information about the persons to whom those files related, the public interest that supported the decision in Rose would lave been inapplicable."76 Thus, it is arguable that Reporters Committee, through a retrospective analysis of Rose, inplicitly sanctioned the application of the stricter public interest requirement under Exemption 6.

Moreover, the strict public interest requirenent can be applied to Exeinption 6 without destroying the distinction between the standards incorporated under Exemptions 6 and 7(C). If a request would not shed light on government operations, then it would not qualify for balancing under eitlier exemption and the requested information could be withheld. If the information would sled light on government operations, then that information would have a valid public interest. However, the weight of that particular public interest would still liave to be balanced against the mvasion of privacy. It is in the balancing process that tlie different standards einployed under Exeinptions 6 and 7(C) arise, a more substantial public interest being required under Exeinption 7(C). ${ }^{77}$

Finally, although broadly construing Exemption 6 and equating it witl Exeinption 7(C) inay contradict a formalistic interpretation of the FOIA language, that application is not unsound. The purpose of the FOIA should be to provide citizens with the riglit to be informed about "what their government is up to," not to require the governinent to be a central depository of information about private citizens, accessible at the request of any person for any reason. The latter notion would place an undue burden on the government, and would render all personal information "fair game."78

73. 425 U.S. 352 (1976) (involving a request for the case summaries of Air Force Academy honor and ethics hearings).

74. Reporters Committee, 489 U.S. at 773-74.

75. Rose, 425 U.S. at 372.

76. Reporters Committee, 489 U.S. at 774.

77. See Federal Labor Relations Auth. v. Department of the Treasury, 884 F.2d 1446, 1451-52 (D.C. Cir. 1989) ("Although the context in Reporters Committee was ... exemption 7(C), we see no reason why the character of the disclosure interest should be different under exemption $6 . .$. . [The] difference between [the standards of exemption 6] and exeinption 7(C) goes only to the weight of the privacy interest needed to outweigh disclosure.").

78. It is important to emphasize that Exeinption $7(C)$ has the effect of protecting individual citizens from invasions of privacy resulting from the probable humiliation, entarrassment, and 
b. Requiring a requester to demonstrate that requested information would shed light on government operations when challenging agency withholding under Exemption 2. Although it may be possible to endorse the application of the Reporters Committee public interest standard under Exemption 6 because of the similarities between Exeinptions 6 and 7(C), the Reporters Committee requirement that requests inust shed higlt on the operation of the government seems less justifiable under other FOIA exemptions. Nevertheless, not everyone rejects the possibility of requir$\mathrm{mg}$ the use of that standard outside of Exemptions 6 and 7(C). This is evidenced by a dissent filed by U.S. District Judge Revercoinb, sitting by designation with the D.C. Circuit, in Schwaner v. Department of the Air Force, ${ }^{79}$ an Exemption 2 case.

Exemption 2 of the FOIA provides that the statute's inandatory disclosure requirements do not apply to "matters that are ... related solely to the internal personnel rules and practices of an agency . . ." 80 In Schwaner, an insurance agent requested a hist of names and addresses of certain military personnel as a source of potential customers. ${ }^{81}$ Setting out the scope of Exemption 2, the court stated:

Our cases have sought to give exemption 2 some structure by adopting a two-step process. "First, the material withheld should fall within the terms of the statutory language." If so, the agency may defeat disclosure by proving that either "disclosure may risk circumvention of agency regulation," or "the material relates to trivial administrative matters of no genuine public interest." 82

Having ordered disclosure because the information did not satisfy the first part of the two-step analysis, the court did not reach the second step, "which ... would entail the weighing of the 'public interest' in disclosure against the government's interest in avoiding the burden of producing the data." 83

Judge Revercoinb dissented, expressing his behef that the requested material was of no "genuine public interest." 84 Judge Revercoinb ana-

stigma associated with a criminal investigation. As such, it represents a compromise, justifying the government's decision to withhold information from one group of citizens in the interest of another.

79. 898 F.2d 793, 798 (D.C. Cir. 1990) (Revercomb, J., dissenting).

80. 5 U.S.C. $\S 552(b)(2)(1988)$.

81. Schwaner, 898 F.2d at 794.

82. Id. (citations omitted). See Department of the Air Force v. Rose, 425 U.S. 352, 369-70 (1975) ("The general thrust of [Exemption 2] is smiply to relieve agencies of the burden of assembling and maintaining for public inspection matter in which the public could not reasonably be expected to have an interest.").

83. Schwaner, 898 F.2d at 798.

84. Id. at 801 (Revercomb, J., dissenting). The requirement of a "genuine public interest" stems from Rose, 425 U.S. at 369 ("Exemption 2 is not applicable to matters subject to such a genuine and significant public interest."). 
lyzed the scope of the public interest by referring to Reporters Committee:

Whether information sought under FOIA is a matter of genuine public interest will depend on whether the request serves FOIA's core purposes, i.e., "to ensure that the Government's activities be opened to the sharp eye of public scrutiny." In essence, the question is whether the information sought would improve the public's understanding of the way in which government operates. ${ }^{85}$

Consequently, because he found that the personnel hist was unrelated to the FOIA's purpose, he concluded that the list could be withheld. ${ }^{86}$

It is questionable whether such a strict public interest standard should be utilized under Exemption 2. Indeed, case law suggests that courts should be lement when dealing with public interest under Exemption 2. For example, in Founding Church of Scientology, Inc. v. Smith, ${ }^{87}$ the D.C. Circuit noted in a footnote that "given the presumption favoring disclosure expressed in FOIA, a reasonably low threshold should be maintained for determining when withheld administrative material relates to significant public interests." 88

The Reporters Committee public imterest standard, however, entails more than a mere "reasonably low threshold," and therefore, it should not be utilized under Exeinption 2. Exemption 2, unlike Exeinption 7(C), does not need a high threshold because the public interest is not balanced against an invasion of personal privacy-a serious concern warranting extra protection. Rather, the public interest is balanced against an administrative concern. Regardless, because Exemption 2 potentially

85. Schwaner, 898 F.2d at 800 (citation omitted).

86. Id. at 801 .

87. 721 F.2d 828 (D.C. Cir. 1983).

88. Id. at 830 n.4 (citations omitted) (emphasis added). Subsequently, in Army Times Publishing Co. v. Department of the Army, 684 F. Supp. 720 (D.D.C. 1988), the district court concluded that a newspaper publisher's request for records containing names and addresses of Army personnel satisfied the low threshold, stating:

[G]iven the high regard in which the Army Times [newspaper] appears to be held by members of the service, military officers, and the public generally, and the importance of open communication on military issues affecting this country, . . . the broad circulation of the Army Times is in the public interest.

Id. at 724. Similarly, in Retired Officers Ass'n v. Dept. of Navy, 716 F. Supp. 662 (D.D.C. 1989), ordered vacated in part on reconsideration, 744 F. Supp. (D.D.C. 1990), the court, citing to Founding Church, found a valid public interest in that:

Plaintiff, a non-profit organization formed to promote the interests of retiring and retired officers of the military, imtends to use the requested names and addresses solely for the purpose of notifying retired and retiring officers ... of its existence. Plaintiff promotes the interests of its members . . . by lobbying . . ., kecping members informed of government activities affecting them, and assisting members in obtaining benefits to which they are entitled.

Id. at 665. Neither Army Times nor Retired Officers involve a public interest that would pass under Reporters Committee's stringent public interest standard, because they do not shed light on government operations. 
involves a public interest inquiry, and because the court in Reporters Committee discussed at length what constitutes a valid public interest, courts may attempt, as Judge Reverconnb advocated, to raise the public interest thresliold in future Exemption 2 determinations.

In conclusion, Reporters Committee lias had an impact on the public interest standard necessary to trigger disclosure of information under certain FOIA exemptions. As a result, courts are inore likely to require requesters who challenge agency nondisclosure to deinonstrate that the requested information will shed hight on government operations. Although inost relevant 1990 decisions have found alleged public interests insufficient, ${ }^{89}$ cases sucl as Ray demonstrate that the public interest requirement, althougli difficult to satisfy, is not an impossible burden. Several courts have since found interests sufficiently "public" to warrant disclosure. 90 Yet Ray may demonstrate another point: Courts may ac-

89. For example, in KTVY-TV v. United States, 919 F.2d 1465 (10th Cir. 1990), a television station sought disclosure of the identities and statenents of the interviewees of an internal postal service investigation, instigated after a postal enployee shot and killed 14 postal workers. Id. at 1467-68. The court found no public interest in knowing "whether the shootings could have been avoided." Id. at 1470. In Simon v. Department of Justice, 752 F. Supp. 14, 15 (D.D.C. 1990), plaintiff sought a record about himself created by the FBI in connection with a 1951 investigation into violatious of the Internal Security Act of 1950,50 U.S.C. $\S \S 781-798$ (1988). Plaimtiff alleged that the public had an interest in knowing that the FBI investigated innocent people for colninunist affiliations. Id. at 17. The court found the asserted public interest lacking, expressing that, although the plaintiff inay have had a "pressing interest," $i d$. at 19 n.5, in knowing the "identity of FBI agents, governinent einployees, and others" related to the requested information, disclosure would not provide information "about what their government is up to." "Id. at 19 (quoting Department of Justice v. Reporters Comm. for Freedom of the Press, 489 U.S. 749, 773 (1989)). In Stone v. FBI, 727 F. Supp. 662 (D.D.C. 1990), aff'd, No. 90-5065 (D.C. Cir. Sept. 14, 1990) (unreported) (1990 WL 134431), scliolars studying the assassination of Senator Robert F. Kennedy sought disclosure of the names of lower-level FBI and law enforcement personnel involved in the assassination investigation. Id. at 663. Plaintiffs alleged a public interest in a more accurate history of the Kennedy assassination. Id. at 666. The court rejected this asserted interest, because "releasing the names of lowerlevel agents would not inform citizens about what their governunent was up to nor would it reveal how the FBI conducted the investigation." Id. at 667. In Fitzgibbon v. Secret Serv., 747 F. Supp. 51 (D.D.C. 1990), a historian who researched alleged plots by the regine of a former head of state of the Dominican Republic to assassinate President Kennedy or kidnap his daughter, id. at 54, sought FBI and Secret Service records, alleging a public interest in that the records "Inay shed light on a plot by agents of the ... regine." Id. at 59. The court rejected this contention, expressing that it was "not a public interest within "the basic purpose of [the FOIA] to open agency action to the light of public scrutiny." "Id. (quoting Reporters Committee, 489 U.S. at 774).

90. For example, in Dunkelberger v. Departinent of Justice, 906 F.2d 779 (D.C. Cir. 1990), a reporter sought einployment records of an FBI agent to learn about the agent's alleged suspension for unisconduct during an investigation. Id. at 779. The plaintiff asserted a public interest in "the public's right to be informed 'about intentional over-stepping by an FBI agent in his dealings with a political figure and the drug scene.' " Id. at 782 (quoting Appellant's Brief at 1). The court, after an in camera review of the withheld information, found nothing in the record to support the plaintiff's suspicion, but implied that if relevant information were included, the public interest would be suffcient to trigger disclosure. Id. In Bretti v. Departinent of Justice, No. 88-CV-328 (N.D.N.Y. June $18,1990)$ (1990 WL 84366) (1990 U.S. Dist. LEXIS 7514), the plaintiff sought disclosure of tapes 
cept a plaintiff's opportumistically-phrased public interest claim that arguably would not have been accepted in Reporters Committee. Thus, courts may not actually be restrained by Reporters Committee; they may still disclose at their discretion if they are able to find an indirect public interest in a request, no matter how far-fetclied it may seem.91

\section{B. Broadening the Threshold of Exemption 6 While Distinguishing Between Lexical and Non-Lexical Information: New York Times Co. v. NASA.}

In perluaps the most significant decision rendered under the FOIA in 1990, an en banc majority of the D.C. Circuit held in New York Times Co. v. NASA ${ }^{92}$ that the audio portion of a tape recording (as opposed to the written transcript of that tape) is potentially exempt froin disclosure under Exemption 6. Specifically, the majority lield that the audio portion of a tape recording that contained luman voices is a "similar file" (thereby meeting the thresliold requirement of Exemption 6), because human voice inflections constitute the type of personal information that may warrant special protection. ${ }^{93}$ The decision lias the potential to curtail future access under the FOIA via Exemption 6.

Exemption 6 permits agencies to withhold "personnel and medical files and similar files the disclosure of which would constitute a clearly unwarranted invasion of personal privacy."94 Judicial review of agency withholding nnder Exemption 6 involves a two-part analysis: First, as a threshold matter, the requested information must be contained in person-

and transcripts that were used against him in his criminal trial. Id. at 1 (LEXIS pagination). Plaintiff asserted a public interest in that the disclosure would "prove that exculpatory statements were redacted from ... transcripts admitted at trial." Id. at 5. The court found a valid public interest in the public benefitting from the potential of exposing that criminal enforcement agencies followed improper procedures. See id. at 6. In Painting Indus. Mkt. Recovery Fund v. Department of the Air Force, 751 F. Supp. 1410 (D. Haw.), reh'g denied, 756 F. Supp. 452 (D. Haw. 1990), plaintiff sought disclosure of certified payroll records of a painting contractor on a imilitary housing contract that contained employee names, addresses, plione numbers, and social security numbers. Id. at 1411-12. The plaintiff alleged a public interest in assuring that the Air Force complied with its enforcement duties under the Davis-Bacon Act, 40 U.S.C. $\$ 276 a$ (1988). The court agreed, and ordered disclosure of the names, addresses, and plione numbers. Id. at 1417.

91. For exainple, in Ray, the plaintiffs had an interest in not being deported. To be sure, they sought information about the Haitian government activities, namely, how they treated returned Haitian nationals. Yet the court was wilhing to find an mdirect public interest in assuring that the U.S. government was adequately monitoring the Haitian government. It appears that almost any request can be claracterized as having an interest in monitoring the U.S. government. For example, the disclosure of rap sheets could very well indicate whether the government was accurately inaintaining criminal history information.

92. 920 F.2d 1002 (D.C. Cir. 1990) (en banc).

93. See id. at 1004 .

94. 5 U.S.C. $\$ 552$ (b)(6) (1988). See supra notes 52, 67-68 and accoinpanying text (discussing Exeinption 6 and comparing and contrasting it with Exemption $7(\mathrm{C})$ ). 
nel, medical, or "similar" files; second, if within such a file, disclosure of the information must constitute a clearly unwarranted invasion of personal privacy. ${ }^{95}$ The latter requirement results in a balancing process similar to that utilized under Exemption 7(C). ${ }^{96}$ The former requirement, specifically the scope of "similar files," was at issue in New York Times.

The leading interpretation of the scope and meaning of the phrase "similar files" under Exemption 6 is the Supreme Court's landmark decision, Department of State v. Washington Post Co. ${ }^{97}$ In Washington Post, the Court rejected the D.C. Circuit's holding that "similar files" referred only to those files containing information "of the same magnitude-as highly personal or as intimate in nature-as that at stake in persounel and medical records." 98 After analyzing the legislative history of Exemption 6, the Court concluded that it did "not think that Congress meant to limit Exemption 6 to a narrow class of files containing only a discrete kind of personal information. Rather, '[t]he exemption [was] intended to cover detailed Government records on an individual which can be identified as applying to that individual." "99 Thus, although the threshold requirement appears to focus on the type of agency file involved, the threshold is satisfied as long as the requested information, however stored, applies to a particular individual. The fact situation presented in New York Times, however, proved to be a difficult application of Washington Post.

New York Times involved a FOIA request by the New York Times Coinpany (the "Times") to NASA for the audio tape recording of the voice communications between crew ineinbers of the space shuttle Challenger, and between the crew and ground control, immediately before the Challenger exploded. ${ }^{100}$ NASA provided the Times with a written transcript of the communications, but refused to release the actual audio tape. ${ }^{101}$ Consequently, the Times filed suit.

95. See Department of State v. Washington Post Co., 456 U.S. 595, 598 (1982).

96. See supra notes $15-17$ and accompanying text.

97. 456 U.S. 595 (1982).

98. Id. at 598 (quoting Washington Post Co. v. Department of State, 647 F.2d 197, 198-99 (D.C. Cir. 1981), rev'd, 456 U.S. 595 (1982)).

99. Id. at 602 (quoting H.R. REP. No. 1497, 89th Cong., 2nd Sess. 11 (1966), reprinted in 1966 U.S. CODE CONG. \& ADMiN. NEWS 2418, 2428).

100. New York Times Co. v. NASA, 920 F.2d 1002, 1004 (D.C. Cir. 1990) (en banc). The space shuttle Challenger, carrying seven crew members, exploded 73 seconds after hift-off on January 28, 1986. The Times allegedly sought the tape to ascertain whether the astronauts sensed any problems in the operation of the shuttle that may have caused the explosion.

101. Id. In denying the request, NASA explained that "the privacy of the families of the astronauts would be invaded significantly by its release because it would subject them to hearing the voices of their loved ones, an intrusion on their grief which certainly would exacerbate feelings of 
In the district court, NASA invoked Exeinption 6, contending, with respect to the threshold requirement, that the requested tape was a "similar file." 102 The court disagreed, stating that "[i]t [was] evident throughout the Supreine Court's opinion in [Washington Post] that the Court presumed that a record can be considered a 'sinilar file' only where it contains personal information about a particular person." 103 Because the court found it "undisputed that the Challenger tape . . . contain[ed] no [personal] imformation about the astronauts or their family ineinbers," the tape was not a "sinilar file." 104 Accordingly, the court ordered NASA to release the tape. 105

On appeal in the D.C. Circuit, a divided panel affirmed the district court's decision. ${ }^{106}$ The D.C. Circuit framed the issue as "whether the sound of the human voice commuricating nonpersonal information will alone raise the tape to the level of a similar file for purposes of Exemption 6."107 NASA argued "that the human voice, being unique to each mdividual, "clearly is information about the imdividual and identifiable as such." "108 Specifically, NASA contended that the astronauts' voice inflections constituted the personal information necessary to trigger "similar file" status. ${ }^{109}$

The D.C. Circuit noted, however, that although Washington Post construed "similar files" broadly, the Supreme Court acknowledged in a footnote that " [i]nformation unrelated to any particular person presumably would not satisfy the threshold test.' "110 Following the rhetoric of the Supreine Court, the D.C. Circuit concluded that the tape did not contain personal information and therefore was not a "similar file."111 This conclusion was influenced by a concern that a contrary holding would invariably render every audio tape recording of human vocalizatiou a "similar file," regardless of the tape's content, because "every per-

hurt and loss." New York Times Co. v. NASA, 679 F. Supp. 33, 35 (D.D.C. 1987), aff'd, 852 F.2d 602 (D.C. Cir. 1988), rev'd, 920 F.2d 1002 (D.C. Cir. 1990) (en banc)).

102. New York Times, 679 F. Supp. at 35.

103. Id. at 36.

104. Id.

105. Id. The district court did not need to consider the other aspect of an Exemption 6 reviewwhether releasing the tape "would constitute a clearly unwarranted invasion of privacy." 5 U.S.C. § 552(b)(6) (1988).

106. New York Times Co. v. NASA, 852 F.2d 607 (D.C. Cir. 1988).

107. Id. at 605 .

108. Id. at 604 (quoting Brief for Appellant at 15).

109. Id.

110. Id. at 605-06 (quoting Department of State v. Washington Post Co., 456 U.S. 595, 602 n.4 (1982)).

111. Id. at 606. The court argued that calling "the sound of a human voice 'personal information' distorts the plain meaning and common understanding of the phrase, as well as the meaning Congress ascribed to it." Id. 
son's voice is essentially unique."112 The court adnıonished that a focus on the nianner of conveyance would render nieaningless the threshold test of Exeniption 6.113

On rehearing en banc, the D.C. Circuit, in a six-to-five decision, held that the Challenger tape was indeed a "similar file" under Exenıption 6 . The case was then renianded to determine whether disclosure would constitute a clearly unwarranted invasion of personal privacy.114 The inajority, Judge Douglas Ginsburg writing, began by expressing that "[t]he FOIA inakes no distinction between inforination in lexical and that in non-lexical form"; 115 both are subject to the FOIA's niandatory disclosure requirements and exemptions. Noting that "[t]he lexical and non-lexical aspects of a file may convey different infornnation,"116 the majority imphicitly endorsed a bifurcated analysis of agency-withheld records. Thus, a court must analyze the lexical and non-lexical aspects of requested information independently to determine the validity of agency withholding under the FOIA. ${ }^{117}$ Having bifurcated its examination of the Challenger crew's communications, the inajority focused on the audio tape, specifically the voice infiections of the crew, to determine whether that niformation constituted a "similar file" within the meaning of Exenuption 6.

\section{Id. at 607 . The court elaborated:}

If, for example, a governmental official gave a public speech about the activities of a governmental agency, a tape of the speech automatically would be a similar file despite the fact that it contains no information personal to the official or anyone else. . . .

Moreover, accreditation of NASA's argument that the uniqueness of the individual astronauts' voices renders the tape a "similar file" would lead to imcongruous results in analogous contexts. Since handwriting is identifiable as the work of a particular individual, by NASA's rẹasoning every handwritten document would also become a similar file. Id.

113. Judge Douglas Ginsburg filed a lengthy dissent. He found that Washington Post's statement that information applying to a particular individual satisfied the "similar file" threshold was dispositive of the issue. He beheved that the astronauts' voice inflections "applied to" the astronauts, and therefore were "personal information." See id. at 607-12 (Ginsburg, J., dissenting). The substance of Judge Ginsburg's dissent was later accepted by the majority opinion in an en banc rehearing of New York Times, which reversed the divided panel's disclosure order. See infra notes 114-25, 133-39 and accompanying text.

114. 920 F.2d 1002, 1009-10 (D.C. Cir. 1990) (en banc). The decision was split along political lines; the so-called "conservative" judges expressed the view that the tape was a "similar file." See DC Circuit Again Changes Privacy Equation, ACCESS REP., Dec. 12, 1990, at 2.

115. New York Times, 920 F.2d at 1005. The court implied that "lexical" is tantamount to "written," and therefore that non-lexical information encompasses all non-written aspects of information. For example, a picture or audio is non-lexical information, but a transcript of the audio is lexical. See id.

116. Id.

117. The court implicitly drew an analogy between an audio tape together with its written transcript, and a "textual report accompanied by a picture." Id. The court stated that a combined text and picture provide more information than the text alone, and that "[i]n a particular case, the picture might be exempt from disclosure while the text is not (or vice versa)." Id. 
The majority deferred to Washington Post when it examined the scope of the "similar file" threshold. It stated that "[t]he information need not be intimate; the threshold for application of Exemption 6 is crossed if the information merely "applies to a particular individual" "18_the threshold is "minimal."119 Thus, the important question is not whether an audio tape is similar in form to personnel or medical files, but rather whether the nature of the information contained within that "audio file" is intimate and personal, and therefore similar to the information contained in personnel and medical records.

The majority recognized that, "while the taped words do not contain information about the personal hives of the astronauts, disclosure of the file would reveal the sound and inflection of the crew's voices during the last seconds of their hives." 120 The majority concluded that because the astronauts' voice inflections were particular to the imdividual astronauts, the audio tape qualified as a "similar file" under Exemption 6 of the FOIA. In reaching this conclusion, the majority rejected the panel's theory that characterizing voice inflections as personal information would invariably result in every audio tape recording being deemed a "similar file" regardless of its content. ${ }^{121}$ First, the majority accused the panel of failing "to acknowledge that information is not conveyed by words alone": The information communicated by the words and voice inflections were distinguishable. ${ }^{122}$ Second, the inajority disagreed with the panel's contention that recognizing non-lexical information as personal information would render the similar-files threshold ineanimg-

118. Id. at 1006 (quoting Department of State v. Washington Post Co., 456 U.S. 595, 602 (1982)) (emphasis added).

119. Id. (quoting Washington Post Co. v. HHS, 690 F.2d 252, 260 (D.C. Cir. 1982)). The court explained that a good reason exists for a minimal threshold:

[I]nformation that fails to cross that threshold must be released without regard to any invasion of personal privacy that may result, and without regard to whether there is a sufficient public interest in its release to warrant the harm caused by that invasion of privacy. A threshold that excludes too inuch would undermine what the Supreme Court described as the Congress's objective of "provid[ing] a proper balance between the protection of an individual's right of privacy and the preservation of the public's right to Government information."

Id. (quoting H.R. REP. No. 1497, 89th Cong., 2d Sess. 11 (1966), reprinted in 1966 U.S. CoDE CoNG. \& ADMIN. News 2418, 2428, quoted in Washington Post, 456 U.S. at 599). The second step of Exemption 6 review-the weighing of public and privacy interests to preclude an unwarranted invasion of personal privacy-serves as a filter that blocks information that should not be disclosed.

120. Id. at 1005.

121. New York Times Co. v. NASA, 852 F. 2d 602, 607 (D.C. Cir. 1988), rev'd, 920 F.2d 1002 (D.C. Cir. 1990) (en banc).

122. New York Times, 920 F.2d at 1006. The court made an analogy for support, stating: "Reading the hibretto of a Verdi opera is not the same as hearing the opera performed. So, too, the ineaning of Marc Antony's speech over the body of Caesar is not to be found in the disembodied words on the printed page, but in the voice that contradicts them." Id. 
less. ${ }^{123}$ The threshold would retain meaning, argued the majority, because "surely millions, perhaps billions" of government files lack nonlexical information. ${ }^{124}$. Furthermore, even when government files do contain information beyond mere words, not all non-lexical information can be traced to a particular individual. For example, a file may contain unidentifiable voices or voices of multiple parties. ${ }^{125}$

The dissent ${ }^{126}$ criticized the majority for holding, as they understood it, "that if an identifiable individual is somehow connected with a Government file, that file automatically becomes a 'similar file' under Exemption 6." 127 To be a "similar file," the dissent argued, "a file must be a 'detailed Government record[] on an individual which can be identified as applying to that individual," "128 and "it must contain personal information about the subject of the file." 129 The dissent argued that the language of Exemption 6, its legislative history, and Washington Post all make clear that the personal information that triggers "similar file" status "cannot be information about the author or maker of the file unless

123. Id.

124. Id

125. Id. Or, as the court asserted, "the financial records of a large corporation ... still do not pass the threshold because they do not contain information 'personal to any particular individual." " Id. at 1007. Indeed, the Supreme Court emphasized in Washington Post that a broad construction of "similar files" would not destroy the threshold requirement of Exemption 6: "[T] here are undoubtedly unany Government files which contain information not personal to any particular individual .... Information unrelated to any particular person presumably would not satisfy the threshold test." Department of State v. Washington Post Co., 456 U.S. 595, 603 n.4 (1982).

126. See New York Times, 920 F.2d at 1010 (Edwards, J., dissenting). Then-Chief Judge Wald and Judges Mikva, Ruth Bader Ginsberg, and Robinson joined Judge Edwards in dissent.

127. Id. at 1012.

128. Id. at 1011 (quoting Washington Post, 456 U.S. at 602). By this requirement, the dissent implies that information that happens to have personal qualities or is somehow connected with an individual is not sufficient to satisfy Exemption 6. Rather, the dissent appears to conceptualize the traditional government record (e.g., a folder that is stored in a file cabinet and contains a list of someone's past residency or voting record) as the only type of information capable of qualifying as a "similar file." In the dissent's view, voice inflections, apart from the transcribed words, would not fall within that category. Indeed, the dissent makes a strong conceptual argument to this effect:

In Washington Post, the Court did not stray from its conclusion . . . that, in order to be a "similar file," a file must contain personal information. Rather, adhering to that view, the Court expanded the scope of the type of "personal information" that qualified for "similar file" status, rejecting this court's narrower conception aecording to which the information had to be "highly personal or intimate in nature."

Id. at 1014 n.3.

129. Id. at 1011. Explaining its conviction that the FOIA protects only the subject of a file from an imvasion of personal privacy, the dissent noted:

Every Government file . . . has two analytically distinct attributes. One is that it is made or authored by some person or group of persons. Another is that it has a subject, which may or may not be a person. ... Of course it is possible for the author and the subject of a given file to be the same, but they are always analytically distinct for purposes of applying $\mathrm{Ex}$ emption 6.

Id. at 1014. The dissent recognized that there inevitably will be borderline cases making it difficult to discern a file's true subject. Id. at 1014 n.4; see infra note 135 . 
she or he is also the subject of the file"; $; 30$ to hold otherwise would render the "similar files" test meaningless, because every file can be viewed in such a way as to reveal personal information about the creator. ${ }^{131} \mathrm{Be}$ cause the dissent beheved that the astronauts were the authors of the audio "file"-a data-gathermg tape-and uot the file's subjects, it concluded that the tape did not qualify for Exemption 6 protection. ${ }^{132}$

The majority attacked the dissent's author/subject distinction. First, the majority noted Washington Post's instruction that if requested information "applies to a particular individual" then it constitutes a "similar file." 133 Because an author may be a "particular individual," argued the majority, that person may indeed have a protectable privacy interest under Exemption 6. Second, the majority emphatically denounced the dissent's supposition that courts are capable of determining a file's true subject, stressing that not every file has a clear subject. ${ }^{134}$ Under the dissent's approach, argued the majority, every FOIA plaintiff would invariably characterize the file subject im such a way as to influence the determination of disclosability. ${ }^{135}$

For example, the majority noted that whether the astronauts are the subject of the requested tape depends on the information that one seeks from the tape. ${ }^{136}$ One could characterize the subject of the tape as "the operation of the shuttle," as the dissent maintains; ${ }^{137}$ however, the subject also could be characterized as "an air disaster, last words, astro-

130. New York Times, 920 F.2d at 1015 (Edwards, J., dissenting).

131. Id. "For example, a typewritten report or letter reveals a good deal of personal information about its author, including information about the depth and breadth of his or her education (as reflected in such elements as word choice, syntactic felicity, mastery of subject matter), editorial care, ... and so on." Id.

132. Id. at 1018. The dissent characterized, as had the panel inajority, the subject of the tapes as information that concerned the operation of the shuttle immediately prior to its explosion. See id. at 1017.

133. Id. at 1007 (quoting Department of State v. Washington Post Co., 456 U.S. 595, 602 (1982)).

134. Id.

135. Id. The dissent disagreed with this assertion. It recognized that there would be "borderline cases," but suggested that:

[I]n any such case, a court is capable of making a context-specific inquiry to determine what or who is the subject of a fle, taking into aecount such factors as the purpose for which an agency created and maintains the file and the understanding of the person who is possibly its subject.

In all cases the court's assessinent would turn upon the information actually contained within the file .... Contrary to the inajority's suggestion, posturing by the parties, such as how "opportunistically" they characterize the subject of a file, or what sort of information they hope might be extracted froin it, would obviously be quite beside the point of the court's central inquiry: whether the file actually contains personal information about a particular individual.

Id. at 1014 n.4 (Edwards, J., dissenting).

136. Id. at 1007 .

137. Id. at 1011 . 
nauts, [or] voices of famous people."138 Regardless, the author/subject distinction was unworkable; it led to an inquiry, contrary to the holding of Washington Post, into the nature of the file, as opposed to simply whether the information "applies to a particular individual."139

The majority and the dissent disagreed on several points, but at the foundation of both opimions hes a fundamental point of divergence: the interpretation of Washington Post. Although both groups allege support for their positions from Washington Post, it appears that the holding in that case was overly broad and unworkably vague in relation to the facts of New York Times. The en banc inajority in New York Times reads Washington Post liberally. For tle most part the majority finds support froin the Court's broad statement tliat information "applying to a particular individual" satisfies the "similar files" threshold. In the majority's view, the voice inflections applied to the particular astronauts on board the Challenger, and therefore the tape constituted a "similar file." The dissent, however, reads Washington Post as requiring more than a inere connection between a file and an identifiable individual: The file must contain personal information about a particular individual. The dissent apparently envisions the traditional agency file (sucl as a inedical or personnel file) in which personal information, perlaps biographical statistics, is mamtained. Consequently, the dissent views the tape as contaiming inerely stateinents regarding shuttle operations, and not personal information.

In light of its vagueness, the Washington Post decision provides little assistance for the resolution of the issues presented in New York Times. The apphication of Washington Post's "similar file" standard in general, and in New York Times specifically, ultimately leads to the following question: What is "personal information" (such that privacy concerns may be justified)? This query necessarily involves a seinantic inquiry into

138. Id. at 1008 .

139. Id. at 1009. In addition to a general rejection of the author/subject distinction, the court attacked the dissent's proposed "context-specific" inquiry to deal with those borderline files in which the file's subject is difficult to discern. The court admonished that a context-specific inquiry "fails to recognize that the relevant context is a function of the purpose of the inquiry." Id. at 1008. In searching for a file's subject, "one could stop arbitrarily at any point and announce a result, as one likes." Id. For example:

[S] uppose ... that someone doing research for a biography of [one of the astronauts] seeks disclosure ... of "all cockpit and other voice recordings of [that astronaut]." By the dissenters' approach, .... . [d]isclosure would thus depend upon whether the tapes are scattered among files relating to different missions, as opposed to being collected in [a] single file ....

An inquiry into the reason a file was created, or the manner in which it is maintained, does not appear to be any different from an inquiry into the label on the file, which the Supreme Court emphatically rejected in Washington Post.

Id. at 1008-09. 
the connotations of "personal" and "information." In the abstract, these questions are understandably difficult to answer. In relation to a specific factual situation, as evidenced by New York Times, the answer proves to be no easier to ascertain.

At the district and appellate levels, the courts hearing New York Times confronted the meaning of "personal information" both explicitly and implicitly. The district court reasoned that a government record must contain personal information to be considered a "similar file," and summarily concluded that the tape lacked personal information. ${ }^{140}$ The panel majority also emphasized that a file is not "similar" unless it contains personal information, which it implicitly defined as "information somehow related to an individual's life."141 In his dissenting opinion, Judge Ginsburg criticized the panel majority for its narrow conception of "personal information." $142 \mathrm{He}$ argued that the voice inflections were personal information, because they "applied," under the rhetoric of Washington Post, to the individual astronauts. ${ }^{143}$ On reliearing en banc, the debate continued. Here Judge Douglas Ginsburg, writing for the majority, endorsed a broad interpretation of what constitutes personal information, contending that non-lexical information was one type of information that can "apply" to an individual. ${ }^{144}$ The dissent disagreed, finding that the tape lacked information about the personal lives of the astronauts; the dissent found, the tape was not "personal information." 145

Whether voice inflections constitute "personal information" is not a black-and-white issue; rather, it is a subjective determination unanswerable by precedent or legislative history. For the en banc majority, the

140. New York Times Co. v. NASA, 679 F. Supp. 33, 36 (D.D.C. 1987), aff'd, 852 F.2d 602 (D.C. Cir. 1988), rev'd, 920 F.2d 1002 (D.C. Cir. 1990) (en banc).

141. New York Times Co. v. NASA, 852 F.2d 602, 606 (D.C. Cir. 1988), rev'd, 920 F.2d 1002 (D.C. Cir. 1990) (en banc).

142. Id. at 609 (D. Ginsburg, J., dissenting). Judge Douglas Ginsburg stated:

Whatever else [the majority's] use of "personal" means, it is apparently something more than the Supreme Court's test that the mformation merely "applies to a particular individual"; for the information that the Times has requested in this case clearly satisfies that test.... In dictionary terms, the phrase "about an individual" and the word "personal" are virtually synonyinous. The court, however, ineans by "personal" soinething more than "about an individual" since it actually uses both phrases in the same breath. The infiection of a voice, moreover, if it conveys anything at all, conveys something "about an individual." ... What more is required for information to be "personal," then? ... [T] The only indication ... is the court's suggestion that "personal" information is that which is somehow related to an individual's life.

Id. (citations omitted).

143. Id. at 609-10. Judge Ginsburg stated: "What, then, does the court consider to be 'personal' information? Where is the distinction between the ... voice and the personal citizenship, date of birth, and place of birth [regarded as highly personal by Washington Post]?" Id. at 610 .

144. New York Times Co. v. NASA, 920 F.2d 1002, 1006 (D.C. Cir. 1990) (en banc).

145. Id. at 1011 (Edwards, J., dissenting). 
question was determinative of the "similar files" claim. The en banc dissent, however, created a further requirement: Personal information must concern the subject of the file. ${ }^{146}$ The distimction between the author and subject of a file, however, further complicates the issue of whether files that contain voice infleetions or other non-lexical information qualify as "similar files" by adding additional subjective factors to the determination. As Judge Ginsburg properly recognized, it is absurd to suggest that a given file has only one ascertainable subject; the subject of a file varies according to how one perceives that file. ${ }^{147}$ Under sucli an approacli, not only would courts commence self-fulfilling and arbitrary searches for the subject of a file, but FOIA plaintiffs and the government would opportumstically phrase the subject in ways intended to fit their particular needs. Such a result would only add to the confusion of determining whether or not certain records constitute "similar files." Accordingly, the court is correct to reject the author/subject approach offered by the dissent. ${ }^{148}$

\section{Id. ,}

147. Id. at 1008. Judge Ginsburg stated:

[I]t is mechanistic in the extreine to insist that [the operation of the shuttle] is ... the only fair statement of the subject of the tape .... Y Yet insist the dissent does-as though the world were neatly divided and labeled according to the rules of English usage.

....

Suppose that "the purpose for which an agency created and maintains" a file is the study of voice inflections, or research into computerized voice recognition. In a file of audio tapes classified by type of voice inflection, [the Challenger tape] might be under the heading "mortal fear." In a file created in the course of voice recognition research, it might be found under the name of the person whose voice it is. Obviously, there is no unique subject inherent im the text of the file. One could equally well say of the Challenger tapedepending upon the filing system in which the agency "maintains" it-that the subject is an air disaster, last words, astronauts, voices of fanous people, or, as the dissent classifies it, Id. "the operation of the shuttle."

148. As the dissent noted, they knew "of no case ... in which a 'similar file' under Exemption 6 has been construed to cover personal information pertaining to the author or maker of the file." Id. at 1016 (Edwards, J., dissenting). However, this may be true simply because no court bothered making such a ridiculous distinction. The weakness of the dissent's approach is demonstrated by their characterization of the 1967 Apollo I spacecraft incident, in which a fire in the cockpit killed three astronauts. The majority referred to NASA's audio tape of the incident as support for the proposition that the voices on the tape conveyed "additional information that applie[d] to the astronauts in the throes of their deaths." Id. at 1006. The dissent responded with the following weak attempt to distinguish the Apollo I incident from the Challenger explosion:

It is telling that the majority, in order to make the point that voice inflections can convey personal information, inust resort to a case not before us, the 1967 fire aboard the Apollo I spacecraft, in which voice inflections certainly revealed genuinely, even profoundly, personal information. That, of course, is a very different case, one in which the tragic conrse of events-a fire occurring over several minutes-transformed the astronauts into the tape's subjects as well as its authors. Here, however, ... the very suddenness of the tragedy precluded the Challenger tape from assuming that character.

Id. at 1018 (Edwards, J., dissenting). The inajority, straining to discern the dissent's distinction between the Apollo I and Challenger tapes, concluded that "[n]o explanation is, or could be, provided because the approach taken by the dissent offers no criterion of judgment." Id. at 1008. 
In the final analysis, the majority's holding seems appropriate in light of the vague standard ("applying to an individual") set fortl in Washington Post, the difficulty in applying this standard to voice inflections, and the inherent problems with the author/subject distimction. However, the court's decision, although significant, only determined the threshold requirement of Exemption 6 (that it constituted a "similar" file); the court did not decide whether the tape, or any non-lexical information for tliat matter, was actually exeinpt from disclosure under the FOIA. Indeed, as New York Times noted, both Congress and the Supreme Court acknowledge that a broad construction of Exemption 6's threshold test is acceptable, because the operation of Exemption 6 will theoretically be checked at the balancing stage, determining whether a clearly unwarranted invasion of personal privacy would occur. ${ }^{149}$

Yet although the Exemption 6 balancing test may operate as a check on a broad threshold test, a significant externality dilutes that rationaleReporters Committee's stringent public interest standard. ${ }^{150}$ Thus, information that satisfies a broad Exemption 6 threshold test will not be checked by balancing if that information does not shed light on government operations. Therefore, the D.C. Circuit's broad construction of the threshold test, coinbined with its narrow view of what constitutes a valid public interest, may significantly increase agency withholding of information.

Although a narrow public interest standard would seemingly dilute the arguinent that a broad construction of the Exemption 6 threshold is harmless, the majority interestingly counters this by reference to Reporters Committee's categorical balancing. The majority casually noted at the end of its opinion that although there may be concern about allowing material such as voice inflections to pass the threshold of Exemption 6, "all but the most unusual assertion of authorial privacy would easily be disposed of under the categorical approacli to Exeinption 6 claims, without any need to resort to ad hoc balancing." 151 In other words, the mate-

149. Id. at 1009. In Washington Post, the Supreme Court recognized:

The [Senate Judiciary] Committee concluded that the balancing of private against public interests, not the nature of the files in which the information was contained, should limit the scope of the exemption: "It is believed that the scope of the exemption is held within bounds by the use of the limitation of 'a clearly unwarranted invasion of personal privacy." "'

Department of State v. Washington Post Co., 456 U.S. 595, 599 (1982) (quoting S. REP. No. 813, 89th Cong., Ist Sess. 9 (1965)).

150. See supra notes $18,25-26$ and accompanying text. The dissent did not argue or even mention this crucial point.

151. New York Times, 920 F.2d at 1009 (citing Department of Justice v. Reporters Comm. for Freedom of the Press, 489 U.S. 749, 776 (1989)). 
rial could involve such insignificant privacy interests that there could not be "a clearly unwarranted invasion of personal privacy."152

Thus, the majority creates what amounts to "reverse categorical balancing" whereby a court may categorically balance certain types of requested information, by their very nature, in favor of disclosure. Such an approach agam illustrates the seemingly unlimited interpretations of $R e$ porters Committee.

\section{A Virtual Irrebuttable Presumption of Confidentiality Approaching Categorical Non-Disclosure Under Exemption 7(D)}

Another access-restricting developinent occurred in 1990 within the D.C. Circuit, this concerning Exemption 7(D). Exemption 7(D) exempts from disclosure the identity of, and information furmished by, confidential sources in law enforcement investigations. ${ }^{153}$ In Schmerler v. FBI ${ }^{154}$ and Dow Jones \& Co. v. Department of Justice ${ }^{155}$ (a later decision affirming the approach outlined in Schmerler), the D.C. Circuit recognized, in effect, an "irrebuttable" presumption" ${ }^{156}$ that FBI informants are confidential sources under 7(D). The court will presume, and requesters realistically will be unable to rebut, that the sources are confidential. The records are thus exeinpt from the FOIA's inandatory disclosure provisions. The decisions are significant because the court has essentially cut off citizen access to information concerning FBI informants.

1. Schmerler v. FBI. In Schmerler, the plaintiff (Schmerler) requested all information from the FBI that related to the FBI's investigation into the murder of his aunt. The inurder occurred fifty-five years prior to Schinerler's FOIA request. ${ }^{157}$ As part of the inurder investigation, the FBI interviewed several of the victim's colleagues and friends concerning the victim's character. ${ }^{158}$ The issue before the court of ap-

152. Id.

153. 5 U.S.C. $\$ 552(b)(7)(D)$ (1988). Specifically, Exemption $7(D)$ provides in relevant part that the mandatory disclosure requirements of the FOIA do not apply to:

records or information compiled for law enforcement purposes, but only to the extent that the production of such law enforcement records or information ... could reasonably be expected to disclose the identity of a confidential source, .... and, in the case of a record or information compiled by criminal law enforcement authority in the course of a criminal investigation ...., information furnished by a confidential source ....

Id. (emphases added).

154. 900 F.2d 333 (D.C. Cir. 1990).

155. 917 F.2d 571 (D.C. Cir. 1990).

156. Though the presumption is not technically irrebuttable, the court's handling of plaintiff's rebuttal evidence, see infra notes $163-64$ and accompanying text, indicates that the presumption is virtually irrebuttable.

157. Schmerler, 900 F.2d at 334.

158. Id. at $334-35$. 
peals was whether those character sources were confidential such that their names were exempt from the FOIA's mandatory disclosure requirements under Exemption 7(D). ${ }^{159}$

To determine whether the sources were confidential, the court noted that although Exemption 7(D) requires the government to demonstrate that sources were assured confidentiality, "the FBI benefits from a presumption that an assurance of confidentiality was given where the circumstances indicate that the want of an assurance would impair its ability to elicit information. Absent evidence to the contrary, promises of confidentiality are inherently implicit when the FBI solicits information." 160 Consequently, whenever the FBI solicits information during a law enforcement investigation, a strong presumption exists that the FBI extended assurances of confidentiality to the sources of that information.

In the mstant case, the court acknowledged that the FBI's claim stood largely on the presumption of confidentiality because the government's evidence to prove that confidentiality was promised was weak. ${ }^{161}$ Thus, the court placed the burden on Schmerler to rebut the presumption that confidentiality had been extended nearly sixty years earher, statmg that " $[t]$ his burden may be met with evidence demonstratimg that it would be unreasonable to infer from the circumstances surrounding the interviews that confidentiahity had been extended."162

After shifting the burden to the plaintiff, the court next considered the plaintiff's evidence to determine whether the sources were assured confidentiality. Schmerler first asserted that there was no need for confidentiality because the interviewees provided innocuous and favorable background and character information, were friendly to the FBI's investigation, had no reason to fear disclosure, had offered no clues to the murder, and were not exposed to danger. ${ }^{163}$ The court rejected the evidence, however, stating that the evidence concerned tlie substance of the interviews and not evidence of the circuinstances surrounding the interviews, which the court had exphicitly required to meet the burden. ${ }^{164}$ Consequently, the requested names were held to be exempt.

159. Id. at 335-36.

160. Id. at 337 (citation omitted) (emphasis added); see also Miller v. Bell, 661 F.2d 623, 627 (7th Cir. 1981) ("promises of confidentiality are inherently inplicit in FBI interviews conducted pursuant to a criminal investigation"), cert. denied, 456 U.S. 960 (1982).

161. Schmerler, 900 F.2d at 337.

162. Id. (emphasis added).

163. Id. at 337-38.

164. Id. at 338. The conrt arrived at this conclusion after recognizing that " "the availability of Exemption 7(D) depends not upon the factual contents of the docunnents sought, but upon whether the source was confidential and the information was compiled dnring a criminal investigation.' "Id. (quoting Shaw v. FBI, 749 F.2d 58, 61 (D.C. Cir. 1984)). 
In analyzing the significance of Schmerler, it is noteworthy that the court placed the burden on the FOIA plaintiff-in this case the burden to demonstrate that the FBI did not extend confidentiality nearly sixty years earlier. The FOIA, however, explicitly states that "the burden is on the agency to sustain its action."165 Shifting the burden to the plaintiff presents a substantial obstacle for FOIA plaintiffs who challenge an agency's Exeinption 7(D) claim, making it easier for investigative agencies to circumvent the FOIA's goal of maximizing access. For instance, it would appear more difficult for one to estabhish that a promise of confidentiality did not occur than to demonstrate that the promise did occur. This is especially true under the facts in Schmerler, in which the plaintiff was asked to deinonstrate that confidentiality had not been extended nearly sixty years earlier. Moreover, the government would seemingly be in a better position to prove wliether confidentiality had been extended because requesters would rarely, if ever, be a direct party to the interviews in question. ${ }^{166}$

Because the court shifted the burden to the plaintiff to rebut the presumption of confidentiality, the court should have been receptive to the plaintiff's evidence. This was not the case. The court rejected Schmerler's evidence, stating that Exemption 7(D) does not depend on "the factual contents of the documents sought."167 Although the availability of Exeinption 7(D) inay not depend on the factual contents of the documents sought, such evidence would seein relevant to the court's explicit standard for rebuttal: "demonstrating that it would be unreasonable to infer from the circunnstances surrounding the interviews that

Schmerler also argued that the sources would have anticipated that their identities would be revealed because at the time the FBI expected that the sources might be called to testify at trial. Id. Thus, the need for confidentiality would be minimal. The court rejected this "potential witness rule." Id. Contra Lame v. Department of Justice, 654 F.2d 917, 925 (3d Cir. 1981) ("If a source expects he will, at some later date, publicly testify regarding the information he has provided, it may be difficult to imply an assurance of confidentiality.").

165. 5 U.S.C. $\$ 552(a)(4)(B)$ (1988) (emphasis added); see Dow Jones \& Co. v. Department of Justice, 917 F.2d 571, 577 (D.C. Cir. 1990) (Edwards, J., concurring) (Schmerler "seemingly disregarded" that the FOIA expressly provides that the burden is on the agency invoking FOLA exemption); see also S. REP. No. 813, 89th Cong., 1st Sess. 8 (1965) ("Placing the burden of proof upon the agency puts the task of justifying the withholding on the only party able to explain it.").

166. Although no cnrrent FBI euployees may have been directly involved in the 1931 interviews at issue, the agency itself was mvolved and therefore should shoulder the burden. The agency is capable of, for example, creatimg a "paper trail" regarding confidential assurances. See Dow Jones \& Co. v. Department of Justice, 917 F.2d 571, 578 (D.C. Cir. 1990) (Edwards, J., concurring). Judge Edwards apparently endorses the view that because agencies possess information and records relevant to confidentiality, not only are agencies in a better position than requesters to show that sources were confidential, but requesters are really in no position to rebut the government's claim.

167. Schmerler, 900 F.2d at 338; see supra notes 163-64 and aceompanying text (describing Schmerler's evidence). 
confidentiality had been extended."168 It may be impossible to meet the court's requirement without using the factual content of the interviews.

In addition, the court's rejection of the "potential witness rule"169 seems unfair. Although the possibility of testifying at trial may not warrant a per se rule denying the existence of confidentiality, such evidence may be relevant to deinonstrate that it would be unreasonable to infer from the circumstances surrounding the interviews that confidentiality had been extended. Although possibly insufficient when weighed independently, when considered together, Schmerler's evidence appears sufficient to meet the court's burden to compel disclosure. Indeed, if Schmerler's evidence is insufficient, one may wonder what evidence would be acceptable to rebut the government's presumption. By shifting the burden to the plaintiff and then critically examining and disinissing plaintiff's evidence, the court moved beyond a mere presumption of confidentiality to a virtual irrebuttable presumption.

2. Dow Jones \& Co. v. Departinent of Justice. The D.C. Circuit affirmed the approach outlined in Schmerler in Dow Jones \& Co. v. Department of Justice. ${ }^{170}$ In that case, Dow Jones \& Company, Inc. ("Dow Jones") sought access to portions of a letter sent by the DOJ to the House Committee on Standards of Official Conduct. 171 The letter contained a summary of the results of the DOJ's investigation into possible criminal activity by a member of Congress. ${ }^{172}$ Although the DOJ declined to prosecute, the letter (indicating that the investigation had uncovered evidence of improper behavior by the Congressinan) contained information from DOJ interviews that occurred during the investigation. ${ }^{173}$ The DOJ denied the request.

The D.C. Circuit considered whether Exenuption 7(D) applied to the information received froin witnesses during the course of the FBI interviews. ${ }^{174}$ Although notnig that "[a]s with the other FOIA exeniptions, 'the burden is on the agency to sustain its action [under Exeinption 7(D)]," "175 the court nevertheless stated: "But as we reiterated just recently in Schmerler ... 'the law of this Circuit is that in the absence of

168. Schmerler, 900 F.2d at 337.

169. See supra note 164 .

170. 917 F.2d 571 (D.C. Cir. 1990).

171. Id. at 572 .

172. Id. The target of the investigation was Fernand J. St. Germain, who at that time was Chairperson of the House Committee on Banking, Finance, and Urban Affairs.

173. Id.

174. Id. at 575.

175. Id. at 576 (quoting 5 U.S.C. $\S 552(\mathrm{a})(4)(\mathrm{B})(1988)$ ). 
evidence to the contrary, promises of confidentiality are inherently implicit when the FBI solicits information." "176

Dow Jones asserted evidence to rebut the presumption of confidentiality, and claimed that the FBI sources "merely described to the FBI matters which presumably occurred in public view."177 In response to this evidence, the court stated: "We doubt that those who witness a congressman's public behavior-whether other congressmen, lobbyists, or restaurant employees-would typically appreciate being identified as the FBI's witnesses. Public behavior of the congressman is one thing; public identification of the witnesses is quite another." 178 Thus, the court concluded that the sources were confidential.

Dow Jones' evidence, like Schinerler's, would seein to meet the Schmerler burden of "demonstratimg that it would be unreasonable to infer from the circumstances surrounding the interviews that confidentiality had been extended." 179 The court, however, failed to refer to the foregoing standard set forth in Schmerler, stating smiply that it doubted whether, in the typical situation, individuals would appreciate being identified as witnesses to a Congressinan's public behavior. It is unlikely that Congress would draft an exeinption to disclosure that specifically requires that sources be confidential, and support this provision with a general mandate that places the burden on the agency to demonstrate that it has met the exemption's requirements, yet really mean that confidentiahty is presumed, with the burden on the plaintiff to rebut the presumption. It is perhaps more unlikely that Congress would beheve

176. Id. (quoting Schmerler v. FBI, 900 F.2d 333, 337 (D.C. Cir. 1990)). In a footnote, the court acknowledged that Schmerler strengthened the presumption employed in Keys v. Department of Justice, 830 F.2d 337 (D.C. Cir. 1987): "But for the presumption, which Schmerler, in truth, strengthened over that employed in Keys, the case would have come out the other way; the government's actual evidence of confidentiality was rather thin." Dow Jones, 917 F.2d at 576 n.4.

In a concurring opinion, Judge Edwards argued that the "implied confidentiality" approach, utilized in Keys (prior to Schmerler) was a better approach than Schmerler's practically irrebuttable presumption. See id. at 578 (Edwards, J., concurring). Judge Edwards noted that Keys "found implied assurances of confidentiality only upon identifying specific circumstances supporting the inference that confidentiality was necessary to elicit information." Id. Judge Edwards was critical of Schmerler's use of Keys to support the use of a practically irrebuttable presumption. He noted that Keys did not suggest that the FOIA plaintiff has the burden of disproving assurances of confidentiality. Moreover, "[t] ality-that 'promises of confidentiality [are] inherently imphicit' in FBI interviews-merely reports one of the standards in use in other circuits." Id. (quoting Keys, 830 F.2d at 345-46).

177. Dow Jones, 917 F.2d at 576. Dow Jones claimed that the sources informed the FBI merely of the names of persons with whom and where the Congressman had dined. In the absence of personal or business ties between the sources and the Congressman, Dow Jones argued that there was no reason to believe that the sources wanted eonfidentiality. Id.

178. Id. The court further stated that "[w]e think appellant's claim regarding all the witnesses is even weaker than that rejected in Schmerler." Id.

179. Schmerler, 900 F.2d at 337. 
confidentiality would be established merely by a court's doubt that witnesses would appreciate being publicly identified as witnesses.

To be sure, the court did not pretend that plaintiffs who contest agency use of Exemption 7(D) had much chance of prevailing:

We readily admit that the presumption we applied in Keys, and especially in Schmerler, in practical terms coines close to an irrebuttable one. The requester will rarely, if ever, have absolutely solid evidence slowing that the source of an FBI interview in a law enforcenent investigation lias manifested complete disregard for confidentiality. ${ }^{180}$

At this point, one may begin to recognize a similarity between this essentially "irrebuttable" presumption and the categorical approach used by the Supreme Court in Reporters Committee. ${ }^{181}$ Indeed, referring to the Court's comment that "categorical decisions may be appropriate," 182 the Dow Jones court believed that by applying an irrebuttable presumption that all FBI sources interviewed in law enforceinent investigations were confidential sources, it was "merely following the direction the Supreme Court gave [it] in Reporters Committee."183

Was the D.C. Circuit merely following the Court's direction? As previously discussed, it is not clear whetler the Court provided directions on categorical balancing for the lower courts to follow. ${ }^{184}$ It is entirely plausible that, in dicta, the Court recognized categorical balancing as a means to an end solely to justify its loolding im Reporters Committee. Regardless, even if one were confident that the Court condoned categorical analysis generally under Exemption $7(\mathrm{C})$, such an authorization would not appear to encompass Exemption 7(D). The apparent "direction giving" statement in Reporters Committee to which the D.C. Circuit referred was a comment by the Court that "categorical decisions may be appropriate and individual circumstances disregarded when a case fits into a genus in which the balance characteristically tips in one direction."185 The balance to which the Court referred is the Exemption 7(C) public interest/personal privacy balance. Thus, if the Court is indeed authorizing categorical non-disclosure, it appears to be limited to Exemption 7(C), ${ }^{186}$ which perhaps explains wliy the Court refers to the approacli as categorical balancing. ${ }^{187}$

180. Dow Jones, 917 F.2d at 577.

181. See Department of Justice v. Reporters Comm. for Freedom of the Press, 489 U.S. 749 (1989); see also supra notes 19-20, 27-28 and accompanying text (discussing Reporters Committee's categorical approach).

182. Reporters Committee, 489 U.S. at 776.

183. Dow Jones, 917 F.2d at 577.

184. See supra note 38 and accompanying text.

185. Reporters Committee, 489 U.S. at 776 (emphasis added).

186. And perhaps Exemption 6. See supra notes 74-78 and accompanying text.

187. See Reporters Committee, 489 U.S. at 778. 
Moreover, significant differences exist between the categorical approach utilized in Reporters Committee and that suggested in Dow Jones. First, by categorically exeinpting rap sheets the Supreine Court exeinpted a particular type of information. The Court utilized this approach as a surrogate for subjective weighing of intangible factors-personal privacy and public interests-by judges on a case-by-case basis. ${ }^{188}$ Exemption 7(D), however, does not involve such a subjective judgment. A court must determine simply whether the agency interviewed the sources for law enforcement purposes or in the course of a criminal investigation, and whether those sources received assurances of confidentiality. The objectiveness of these determinations obviates categorical decisionmaking. ${ }^{189}$

A second reason why applying a categorical approach under Exemption 7(C) is more justifiable than under Exemption 7(D) is that when the Court categorically balanced under Exemption 7(C), it left imtact the schene of balancing privacy interests against the public interest im disclosure. The Court noted that for certain types of information-rap sleets-the balance will always tip in the direction of withholding. Outside of rap sheets, however, balancing is still required.

A categorical approach under Exeinption 7(D), on the other hand, has the effect of striking language froin the FOIA. By concluding that information solicited during law enforceinent investigations is categorically confidential, courts would render superfluous the language of Exemption 7(D), which requires that the requested information be "furnished by a confidential source." 190 Congress could have easily omitted the adjective "confidential" in the exeinption, but it did not. ${ }^{191}$

Upon losing on appcal im the D.C. Circuit, Dow Jones sought an en banc relıearing, which was demied. ${ }^{192}$ Judge Silberman, joined by Judge

188. Indeed, Reporters Committee noted that "[t]he Court of Appeals majority expressed concern about assigning federal judges the task of striking a proper case-by-case, or ad hoc, balance between individual privacy interests and the public interest in the disclosure of criminal-history information without providing those judges standards to assist in performing that task." Id. at 776.

189. But see infra note 194 (Judge Silberman, concurring in the denial of a relrearing en banc, argued that categorical determinations inade under Exemption 7(D) will alleviate problems associated with subjective, ad hoc decisionmaking. Dow Jones, 917 F.2d at 579).

190. 5 U.S.C. $\S 552$ (b)(7)(D) (1988).

191. See Dow Jones, 917 F.2d at 577 (Edwards, J., concurring). Judge Edwards was not convinced that the government satisfied the statutory burden merely by demonstrating that the FBI interview occurred during a criminal investigation, because such an interpretation would contradict the language of Exemption 7(D), which permits withholding "only if the information is 'furnished by a confidential source." "Id. (quoting 5 U.S.C. $\S 552(b)(7)(D)(1988)$ ). It is arguable that the Dow Jones presunption applies ouly to FBI sources, because those are the sources to which the court refers in its holding. Perhaps other records compiled by a criminal law enforceinent agency contain information furnished by non-FBI sources.

192. Id. at 578 . 
Williams, concurred in the court's order, claiming that "the presumption [of confidentiality] is directed, strictly speaking, not at the burden of proof, but at the quantum of evidence necessary to carry the burden. Fixing the burden of proof on a party is plainly not inconsistent with a substantive rule identifying specific facts that will carry the burden."193 However, although the presumption is technically directed at the quantum of evidence necessary to carry the burden, the effect is the same: The burden of proof is inevitably carried by the plamtiff. Indeed, although the government may, have the burden, the plaintiff bears the burden. ${ }^{194}$

3. Conclusion The presumption of confidentiality represents a product of judicial legislation. ${ }^{195}$ However, even if courts were to exercise restraint and reject the "irrebuttable" presumption im favor of a more leurent "implied confidentiality" standard, there is no guarantee that a court would not achieve the same result-finding an assurance of confidentiality-by according great deference to the government's case. Moreover, the court's "irrebuttable" presumption, although perhaps in violation of the language of Exeinption 7(D), would protect those sources who were assured or who expected confidentiality where the governinent, by lapse of time or mistake, is unable to prove its case. In any event, the decisions ultimately restrict the public's access to certain information regardless of how important that information is to the particular requester

193. Id. at $\mathbf{5 7 9}$ (citation omitted).

194. Judge Silberman attempted to justify the strong presumption, contending:

[T] he FBI would routinely be compelled to produce evidence as to the particular expectations of the interviewee and the agent, and we would be obliged on a case-by-case basis to try to determine just how much confidentiality qualifies as a 'confidential source.' ... [W] seek to avoid ad hoc decisionmaking.

Id. Contra id. at 580 (Edwards, J., dissenting) (Judge Edwards, joined by then-Chief Judge Wald and Judge Mikva, rejected Judge Silberman's theory that the Schmerler presunption was justified to reduce administrative and judicial burdens: "Burdensome or not, we are constrained to enforce the statute as it was written by Congress.").

Judge Silberman concluded with a reference to Department of Justice v. Reporters Comm. for Freedom of the Press, 489 U.S. 749, 776 (1989): "Because at least some element of confidentiality is virtually always present, [Reporters Committee] counsels that we treat such questions generically." 917 F.2d at 579 (emphasis added). But see supra note 38 and accompanying text (arguing that it is not obvious that Reporters Committee authorized mass categorization).

195. See Dow Jones, 917 F.2d at 580 . Judge Edwards referred to Schmerler as a "rather remarkable example of judicial intervention" and an "example of judicial fiat." Id. He concluded that the perils of the majority's course are quite plain:

"[I]f courts were free to 'correct' what they believe to be congressional oversights by construing unambiguous statutes to the contrary of their plain meaning - apart from that rare case in whicb specific legislative history compels such a result-even a good faith attempt to further Congress's goals would open the way to judicial hijacking of the power to legislate." It is not the role of this court to rewrite statutes to satisfy the legislative policy preferences of the judges.

Id. (quoting Consolidated Rail Corp. v. United States, 896 F.2d 574, 579 (D.C. Cir. 1990)). 
or to the general public. In light of the congressional intent to inaximize public access to agency records, the scale slould tip in favor of the public.

\section{Administrative Viewpoints on Electronic FOIA Issues}

In recent years, federal agencies liave become increasingly computerized. With this mass computerization, significant issues are raised under the FOIA, which was written to apply to the paper record systems in place when it was enacted twenty-four years ago. ${ }^{196}$ In 1990, the DOJ's Office of Information and Privacy (OIP) published the results of a government-wide survey ${ }^{197}$ commenced in May 1989 by the DOJ to collect information from individual agencies on agency positions and practices regarding electromic record issues under the FOIA. ${ }^{198}$ The OIP conducted the survey to establish a framework for future uniform governinent policies concerning electronic FOIA issues. ${ }^{199}$ The attention was warranted because the FOIA does not contain any language regarding its application to electromic records. In the absence of any statutory language to guide the agencies, and in light of the fact that the DOJ's guidance over the agencies on FOIA matters is noncompulsory, agency unwillinguess to search or disclose electronic records will significantly dilute the effect of the FOIA ni this largely electromic world. ${ }^{200}$

196. "Much of the difficulty with 'electromic record' issues under the FOIA stems from the fact that Congress could barely envision federal agencies operating in an 'electronic environment' at the time at which the Act was designed." Office of Information and Privacy, Department of Justice, Department of Justice Report on "Electronic Record" FOIA Issues: Part I, FOIA UPDATE, Spring/ Suniner 1990, at 3, 4 [heremafter DOJ Report Part $I$.

197. DOJ Report Part I, supra note 196, at 3; Office of Information and Privacy, Department of Justice, Department of Justice Report on "Electronic Record" FOIA Issues: Part II, FOIA UPDATE, Fall 1990, at 3 [hereinafter DOJ Report Part II].

198. See Office of Information and Privacy, Department of Justice, OIP Takes "Electronic Record" Survey, FOIA UPDATE, Spring 1989, at 1.

199. DOJ Report Part $I$, supra note 196, at 3 . The OIP conducted the survey against the backdrop of recent adninistrative, legislative, and judicial focus on and concern regarding the apphication of the FOIA in an electronic world. See, e.g., House COMm. ON GOVERNMENT OPERATIONS, Electronic Collection and Dissemination of Information by Federal agencies: A Policy OVERVIEW, H.R. Rep. No. 560, 99th Cong., 2d Sess. (1986); U.S. CoNG. OfFice OF TeCHNOLOGY ASSESSMENT, INFORMING THE NATION: FEDERAL INFORMATION DISSEMINATION IN AN Electronic Age (1988) [hereinafter INForming the Nation]; H. PerRitT, JR., Electronic ACQUistTION AND RELEASE OF FEDERAL AGENCY INFORMATION (1988) (report for Administrative Conference of the United States); Federal Information Dissemination Policies \& Practice: Hearings Before the Government Information, Justice \& Agriculture Subcomm. of the House Comm. on Government Operation, 101st Cong., 1st Sess. (1989).

200. Although Congress has not provided any reference to electronic records in the FOIA itself, various conmittee reports have indicated that the FOIA should apply to electronic records as it does to conventional records. See, e.g., H.R. Rep. No. 560, supra note 199; see also infra text aeconipanying notes 243-50 (discussing H.R. REP. No. 927, 101st Cong., 2d Sess. (1990)). 
The existence of electronic record systenis in federal agencies raises significant issues concerning the responsibilities of agencies that handle FOIA requests. For example, does coniputer information constitute an "agency record," thereby subjecting it to the niandatory disclosure provisions of the FOIA?201 Additionally, niust an agency perform new con1puter programming when searching for, processing, or producing records nuaintained in electronic form? ${ }^{202}$ To assess agency opinion and practice relating to these and other electronic issues, the OIP survey identified four niajor issues for agency comment:

A. Does the FOIA require agencies to create new computer programs (or modify existing programs) for search purposes, i.e., in order to search for and retrieve electromic records according to the particular specifications of FOIA requesters?

B. Does the FOIA require agencies to create new computer programs (or modify existing programs) for "processing" purposes, i.e., in order to segregate disclosable from nondisclosable electronic record portions?

C. Does the FOIA require agencies to provide requested records in the particular forms (or database formats) specified by requesters?

D. Is computer software an "agency record" under the FOIA?203

Because the FOIA lacks any language regarding electronic issues, the niost important responses (in terms of public access) are those fron1 agencies that expressed opposition to an "electronic FOIA."

\section{A. Search and Retrieval of Electronic Records}

The FOIA requires that agencies responding to a FOIA request conduct a reasonable search for requested information. ${ }^{204}$ The first survey issue arose out of a recognition that searching obligations will probably differ when an agency maintains an electronic record systeni. A conventional record systenı usually consists of paper records stored in nidividual files imdexed according to specific prearranged subject niatter. An agency search and retrieval in response to a FOIA request is limited to the way that the agency normally searches its files in the course of its opera-

201. The FOIA's mandatory disclosure provisions grant access to "agency records." See 5 U.S.C. §552(a)(3) (1988). However, the Act does not define the term "agency records" and the legislative history is unclear on this point. See McGehee v. CIA, 697 F.2d 1095, 1106, modified in other respects, 711 F.2d 1076 (D.C. Cir. 1983). Thus, the ineaning of the term "agency record" is a frequently litigated issue. See generally Note, The Definition of "Agency Records" Under the Freedom of Information Act, 31 STAN. L: REv. 1093 (1979) (discussing the uncertainty regarding the ineaning of "agency record").

202. See DOJ Report Part I, supra note 196, at 3.

203. Id. at 6.

204. Truitt v. Department of State, 897 F.2d 540, 542 (D.C. Cir. 1990). A question arises as to what extent agencies are obligated to go in order to "reasonably" search an electronic record system. 
tions. ${ }^{205}$ With an electronic systen, however, there exists far greater flexibility and capability to search files through the use of coniputer programming. ${ }^{206}$ Yet if a FOIA request cannot be located under the agency's existing search techniques, the agency will generally deny the request.

The OIP recognized that retrieving information in an electronic systen could result in the creation of new programming. ${ }^{207}$ Furthermore, the OIP cautioned that, although electronic searches may not involve inuch effort in coinparisou to conventional searches, "the potential uses of 'electronic' agency file systeins by sophisticated FOIA requesters are seemingly unlimited-as are the corresponding burdens that such uses could place upon federal agencies." 208

Of the seventy agencies that responded to the first survey issue, fiftythree $(\mathbf{7 5 . 7 \%})$ opposed a requirenent that agencies perform new programming to search for requested records. ${ }^{209}$ Agencies voicing opposition indicated a concern that new programming requirements would result in a significant administrative burden, in terms of their limited resources and their ability to conduct their statutory duties. ${ }^{210}$ Several agencies that voiced opposition to the programming requirennent believed that the "reasonableness" standard could apply to electroinc

205. For example, the Securities Exchange Commission ("SEC") may maintain a file under the subject-matter heading "public offerings" (with a record of each individual public offering that occurred in the past 20 years), and another under the heading "underwriters" (containing the names and addresses of all underwriters). The "public offerings" file may contain information regarding the offering corporation's past and current underwriters. However, a request for "all public offerings ever handled by Merrill Lynch" would not be accessible under the existing subject-matter indexing systein without digging through records of every public offering listed in the "pubhic offering" file. With thousands of public offerings on file, the search for the requested records would be unreasonable. See generally Church of Scientology v. IRS, 792 F.2d 146, 150-51 (D.C. Cir. 1986) ("It is firmly established that an agency is not required to reorganize [its] files in response to [a plaintiff's] request in the form in which it was made.") (quotations omitted).

206. In the SEC example, supra note 205, an electromic system would allow the SEC to merely type "Merrill Lynch" and "public offering" to obtain the requested information.

207. DOJ Report Part I, supra note 196, at 11. "In any event, they involve a manner of "creational" activity that, to say the least, federal agencies are generally unaccustomed to regarding as within their basic FOIA responsibilities." Id. See Forshain v. Harris, 445 U.S. 169, 186 (1980) ("the FOIA imposes no duty on [agencies] to create records") (citing NLRB v. Sears, Rocbuck \& Co., 421 U.S. 132, 161-62 (1975)); Kissinger v. Reporters Comm. for Freedom of the Press, 445 U.S. 136, 152 \& n.7 (1980) (same). Thus, although electronic searches may, in many cases, involve little time or effort, the agency would technically be creating a new record, which they are not obligated to do under the FOIA.

208. DOJ Report Part I, supra note 196, at 12.

209. Id. at 14.

210. Id. Not all agencies were adamantly opposed to the idea; some indicated a willingness to conduct broader, but not unlimited, searches of electronic record systems. Id. at 15 . 
FOIA searcles, but were concerned with the uncertain application of that standard..$^{211}$

\section{B. Processing Electronic Records}

The second issue of the OIP study was "whether agencies are obligated to engage in computer programming for the purposes of 'processing' electronic records under the [FOIA]." 212 Processing occurs in cases in which agencies, after they locate a requested record, must excise exempt portions and disclose non-exempt portions. ${ }^{213}$ Witl conventional paper records, deleting portions of a record involves the straightforward alteration of a copied page. Witl electronic records, lowever, processing is not as simple. Electronic records consist of "electronic impulses" that cannot be manipulated in the same manner as the information printed on a piece of paper. ${ }^{214}$ Althougli an agency could circumvent this problem by primting out the electromic information im conventional form and then processing the information in a conventional manner, the problen1 remains when records are requested in electronic form. Under such a scenario, a question arises whether an agency must engage in coinputer programming to delete exeinpt portions before disclosing the remanider. ${ }^{215}$

The overall agency response to the second survey question was similar to that expressed for the first survey issue. ${ }^{216}$ Thirty-three of the seventy responding (47.1\%) agencies opposed a coinputer programming requirenient for processing purposes; inany expressed the administrative concerns reflected in the responses to the first survey issue..217 Not all agencies agreed, lowever, that the requireinent would necessarily result

211. Id. at 16. The OIP cited a study of electronic record FOIA issues, conducted by the Oflice of Technology Assessnient, that recognized that "drawing lines between reasonable degrees of effort is a difficult task.' " Id. at 16 n.20 (quoting INFORMING THE NATION, supra note 199, at 229). The American Bar Association and the Administrative Conference of the United States, however, recommend a reasonableness standard. Id.

Three agencies (4.3\%) imdicated no opposition to a requirement of coniputer programming for electronic record searches. Fourteen agencies (20\%) indicated no opinion on the issue. Id. at 14. 212. Id. at 17.

213. Id. The processing function is required by the language of the FOIA, which provides that "[a]ny reasonably segregable portion of a record shall be provided to any person requesting such record after deletion of the portions which are exenipt under [the Act]." 5 U.S.C. $\$$ 552(b) (1988).

214. DOJ Report Part I, supra note 196, at 18.

215. Id. The OIP noted that in some circumstances, "where agencies have extensive data-retrieval capabilities built into their 'eleetronic' record systems, the task of segregating exenipt from nonexempt information actually can be a sinple one that should raise no 'processing' issue . . . because the tasks of data retrieval and data segregation can be, in effect, one and the same." Id.

216. Id. at 20. For a full discussion of the responses to the second issue, see id. at 20-21.

217. Id.; see supra text accompanying note 210 . 
in a larger burden. Some agencies indicated that coinputer programming for processing purposes had already been utilized in soine situations. ${ }^{218}$

\section{Requester Preference of Form}

The third survey issue concerned "whether the [FOIA] requires federal agencies to provide requested records in a particular specified form or format," as dictated by a requesters particular preference. ${ }^{219}$ The OIP recognized that choice of format questions can arise even in the context of conventional records, because agencies have inaintained records in many forms other than paper records. ${ }^{220}$ In the electronic context, however, "records can take the widely varying forms of inagnetic tapes, disks and other devices ... [that] can vary greatly in their basic format, technical configuration and operational design-which in turn can yield significant differences in compatibility with various autonated data-processing systems."221 If a requested record is imcompatible with a particular requester's data-processing system, the record will be unreadable and, therefore, useless. Moreover, for a requester to convert the record into a compatible form could be costly and time-consuming.

The OIP noted that the choice of format issue arises in two situations. The first arises when an agency inaintains information requested under the FOIA in more than one format, whether electronic, conventional, or both. Here, the issue is whether the FOIA entitles the requester to choose among the alternatives maintained by the agency. ${ }^{222}$ The second situation arises when an agency nuaintains requested information in only one form, and the agency would have to put the information in a different form to satisfy a request. ${ }^{223}$

In response to the choice of format issue, a nrajority of the agencies (forty-one of the seventy agencies responding (58.57\%)) opposed a requirement that agencies must yield to the requester's choice.224 Many of these agencies were concerned with the potential administrative cost and

218. DOJ Report Part I, supra note 196, at 20. For example, the Federal Trade Commission explained that, with its system, "it is more efficient . . . to segregate information electronically than to produce a complete paper record of the requested information and then delete the nondisclosable information." Id. at 21.

Half of the agencies imdicated no position on the issue, which apparently reflects little agency consideration of the issue. Only two agencies $(2.86 \%)$ mdicated no opposition to the requirement. Id. at 20.

219. DOJ Report Part II, supra note 197, at 3.

220. See id. Microfilm and microflcle arc two exaunples.

221. Id.

222. Id.; see, e.g., Dismukes v. Department of the 1nterior, 603 F. Supp. 760 (D.D.C. 1984).

223. DOJ Report Part II, supra note 197, at 4.

224. Id. at 5. 
burden of such a requirement. ${ }^{225}$ Most favored broad agency discretion on the choice of format issue, although many indicated that agency discretion should be limited by a "reasonableness" standard.226

\section{Are Computer Software Programs "Agency Records"?}

The fourth survey issue, whether software constitutes an "agency record" such that it is subject to the FOIA's mandatory disclosure requirement, was and still is complicated by the fact that the FOIA does not define the term "agency record."227 Moreover, the OIP noted that a further coinplication is that the definition of the term "software" is imprecise. ${ }^{228}$

Considering whether software constitutes a "record," the OIP stated:

A "record" is generally understood to be a medium of one form or another on which information is recorded im order to preserve its content. If computer software is of such character that it does not itself serve to record information, but rather serves merely as the means by which recorded information is manipulated within an automated dataprocessing system, then is it a "record" under the FOIA at all?

…

Thus, the question is whether they are most properly regarded as vessels of information (like data), on the one hand, or as mere tools (like hardware), on the other. ${ }^{229}$

Even assuming that software is a "record," the OIP questioned whether software has the proper connection with an agency to constitute an "agency record." Supreme Court precedent holds that a record is an "agency record" if it is both in that agency's possession and within its control. ${ }^{230}$ Although possession is usually undisputed, the question of "control" is more difficult:

225. Id.

226. Id. at 5, 6. The OIP noted that "[o]verall ... the survey responses indicated very little agency experience in dealing with [the clooice of format] issue to date." See id. at 5 . Of the remaining responding agencies, 27 (38.57\%) expressed no opinion, whereas only two agencies $(2.86 \%)$ favored a requirement that allowed requesters a clioice of format. Id.

227. See supra note 201.

228. See DOJ Report Part II, supra note 197, at 7. The OIP stated:

In common parlance, coinputer "software" is generally understood to be the preprogramned set of instructions according to which data is meclianically inanipulated in a computer or in soine type of automated data-processing equipment. Usually it takes the form of a disk or tape that has been constructed or patterned in such a way as to achieve a precise result when used together with accompanying "liardware."

Id. (footnote omitted).

229. Id. at $7-8$ (citation omitted).

230. Id. at 8 (citing Forsham v. Harris, 445 U.S. 169, 171, 173 (1980) and Kissimger v. Reporters Comm. for Freedom of the Press, 445 U.S. 136, 151, 157 (1980)). 
To determine the question of "control," . . . consideration must be given to the circumstances under which an item of computer software came into an agency's possession.

....

... Put most simply, the issue is whether [an] outside proprietary interest-holder has lawfully retained sufficient control over that software to render any requested FOIA disclosure beyond the agency's own legal power. Consideration of this issue requires an analysis of the factual circumstances and legal conditions involved in each particular case. $^{231}$

Because most agencies obtain software through contractual agreements that may limit the agency's use of that software while maintaining control with the software's owner, a legal question arises whether sufficient control is extended. 232

Of the seventy agencies that responded to the issue, thirteen (18.57\%) believed that software does not constitute an "agency record," and regarded software as "nothing more than a 'tool' used for the manipulation of data."233 Many of tliese agencies expressed concern about software constituting an "agency record," because agencies frequently use commercially-developed software with licensing restrictions and copyriglit protections. ${ }^{234}$ In addition, many of these agencies expressed concern over the security of the government computer systems. ${ }^{235}$

\section{E. Conclusion}

Althouglı the OIP concluded its report with its belief that the study "should provide a firm foundation" to deal witl electromic record issues in the future, agency viewpoints must be taken with a grain of salt. ${ }^{236}$ Most agencies would rather maintain discretion over access to their records, botlı out of a concern over the substance of their information, and because the FOIA presents a real administrative burden and cost.

231. Id. (citation omitted).

232. Id. at 9 .

233. Id. at 10.

-234. Id. at 11.

235. Id. at 12. For example, the Selective Service System was concerned that computer "hackers," if able to examine internal programs, could create viruses to infect the agency's programs. Id.

Twenty-two agencies (31.4\%) expressed that software should be considered an "agency record," at least in some situations. Half of the agencies expressed no position. The OIP attributes this result to possible limited agency experience with the issue. Id. at 10.

236. Representative Bob Wise (D-W.Va.) criticized the OIP's survey in a letter to Attorney General Thornburgh. Wise complained about the way the survey was structured, noting:

[T]he [DOJ's] response to these difficult problems was to take a survey of the views of federal agencies on some of the legal issues involved. Questions of legal interpretation must be decided with reference to the law. Opimion polls have no probative value.... [G]iven the history of agency indifference or outright hostility to the disclosure of information, it cannot be surprising to anyone that agencies generally favor any interpretation of the law that reduces agency disclosure obligations. ... [T] he [DOJ] report also exemplifies the 
Nevertheless, with increased computerization of federal agencies, agency policies toward electromic FOIA issues, in the absence of a specific legislative mandate, will continue to impact significantly the public's ability to access coinputerized records. If Congress does not outline a specific and uniform policy by amending the FOIA, agency opinion, as evidenced by the OIP study, may render the FOIA practically useless in the increasingly electronic world.

\section{Legislative DeVelopments IN THE FOIA IN 1990}

In 1990 the House passed the Paperwork Reduction and Federal Information Resources Management Act of $1990^{237}$ (bill), a bill that, if enacted, would have botli a direct and indirect impact on the future application of the FOIA. The bill is significant for two reasons: It articulates a policy regardnig electronic information, and it would shift adıministrative guidance of the FOIA from the DOJ to the Office of Manageinent and Budget (OMB). Although the bill was not enacted into law, ${ }^{238}$ the possibility of the bill's renitroduction warrants attention.

\section{A. Title I: A Legislative Opinion Regarding the Application of the FOIA to Electronic Records}

The bill represents an amendment to and expansion of the Paperwork Reduction Act of 1980,239 a law designed "to minimize the paperwork burden and niaximize the usefulness of information collected by the Federal government."240 Title I of the bill, although retaining the Paperwork Reduction Act's focus on the reduction of paperwork, expands the 1980 legislation by establishing certain information dissenination policies for federal agencies. ${ }^{241}$ The addition of statutory dissemination policies steins from a recognition that information teclınology lias clianged with the advent of agency electronic systems. ${ }^{242}$

conflict of interest that necessarily arises when hitigation and policy functions are combined in the same agency [(the DOJ)].

ACCESS REP., Jan. 9, 1991, at 12-13. See infra notes 251-59 and accompanying text (noting how the House amendments to the Paperwork Reduction Act would shift FOIA guidance functions from the DOJ to the OMB because of the conflict of interest in the DOJ).

237. H.R. 3695, 101st Cong., 2d Sess., 136 CoNG. REC. 11,895-906 (daily ed. Oct. 23, 1990).

238. The Senate failed to pass the bill before the end of the session.

239. Paperwork Reduction Act of 1980, Pub. L. No. 96-511, 94 Stat. 2812 (codifled as amended at 44 U.S.C. $\$ \S 3501-3520$ (1988)).

240. H.R. REP. No. 927, 101st Cong., 2d Sess. 19 (1990).

241. Id. at $16,20$.

242. Id. at 24. The Report accoinpanying the bill noted:

Technology is raising issues that existimg laws simply do not clearly address. . . The dissemination amendments inade by [the bill] are intended to bring the [Paperwork Reduction] Act squarely into the electronic information age by encouraging Federal agencies to 
Although the bill does not directly amend the FOIA in the context of electronic information, its accompanying policies would affect the FOIA in that context.

The Committee on Government Operations' (Committee) Report that accoinpanied the bill explicitly recognizes the connection between the bill and the FOIA in that botli reflect the policy of providing the public with government information. ${ }^{243}$ However, the FOIA and the bill take different approaches to fulfill that policy: The FOIA is an access statute, wliereas the bill focuses on dissemination. ${ }^{244}$ More importantly, the Report makes clear that policies concerning electronic information under the bill are equally applicable to the FOIA:245

Some consideration was given to the need to amend the FOIA to provide nore specifically for public access to electronic records. . . .

The Committee agrees that the FOIA currently is broad enough to support public access to the electronic records. ... The FOIA already requires agencies to accept FOIA requests for eleetronic records without any distinctions based on content. The FOIA already requires agencies to conduct thorough searches of electronic records using all reasonable ineans, nicluding electronic searches and programming techniques. The FOIA generally requires agencies to inake copies of electronic reeords available in paper format or in electronic formats depending on the needs of the requester. An electronic data base is clearly an agency record ....

disseminate information in electronic formats and in other formats that will be useful to public users.

Id.

243. See id. at $25-27$.

244. Id. at 25. The Report explains:

"Dissemination" refers to the distribution of government information to the public through printed documents or through electronic and other inedia, independent of a legal obligation to respond to a request from the public for the infornation. ... While related in purpose and sometimes in practice, the functions can be analyzed separately. . . . To the extent that public needs are not fulfilled by an agency's dissemination activities, the access Id. provisions of the FOIA may be used to fulfill those needs.

245. The bill explicitly provides that the dissermnation obligations supplement, but do not replace, the provisions of the FOIA. H.R. 3695, 101st Cong., 2d Sess. $§ 103(d)(1990)$. The Senate Report accompanying the Senate proposal to amend the Paperwork Reduction Act of 1980, S. 1742, 101st Cong., 2d Sess. (1990), stated:

[T] he [Senate] bill requires that information dissemination policy developed by . . . any federal agency applies to all government publications in any format (i.e. paper, compact disc, on-line data, etc.).

This change arose because the Committee recognized that the federal government is operating in the electronic information age, and is utilizing alternative information formats on a rapidly increasing basis. The law has not kept pace with these changes. The federal information infrastracture [sic] requires the development of information policies which take into account the advantages and consequences of advances in inforination technology.

S. Rep. No. 487, 101st Cong., 2d Sess. 43 (1990). 
The dissemination [provisions of the bill] underscore the importance of public access to electronic records in support of the existing principles of the FOIA. ${ }^{246}$

The foregoing passage is significant in that it reflects a legislative opinion that favors access to electronic information under the FOIA. ${ }^{247}$ First, the Committee endorses the view that electroinc information constitutes an "agency record."248 Second, the Committee believes that the FOIA requires agencies to conduct searches for electronic information. Third, the Committee also beheves that FOIA requesters may choose the format of their requests, provided that such requests are not unreasonable. 249

In conclusion, Title I of the bill, although actually dealing with affirmative dissemination obligations as opposed to public access, could affect future FOIA disclosure requirements in the realm of electronic records. ${ }^{250}$ The Committee's emphasis on the importance of the public receiving significant government information, and of receiving that information in a manner that fits the public's needs, may influence agency

246. H.R. REP. No. 927, 101st Cong., 2d Sess. $26-27$ (1990) (footnotes omitted). The Report further indicates that agency dissemination of electronic records under the bill may curtail the number of FOIA requests by encouraging the agencies to disseminate inore information. See id. at 27.

247. But cf. supra text aecompanying note 199 (OIP implies that all of these issues are unresolved).

248. The Report states that "[i]mpulses on electronic media, like words and drawing on paper, are records for purposes of the FOIA and inay be requested." H.R. REP. No. 927, supra note 246, at 26 n. 24 .

249. The Report, pointing to Dismukes v. Deparment of the Interior, 603 F. Supp. 760 (D.D.C. 1984) (holding that FOIA requesters do not have a choice of format), notes the controversy over whether the FOIA allows a requester a choice of format. The Report notes the Coinumittee's view that Dismukes was wrongly decided, see H.R. REP. No. 927 , supra note 246 , at 26, probably "because of a lack of judicial understanding of modern information technology .... ." Id. at 26 n.26. Thus, the Committee's view is that "the FOIA permits the requester a choice of obtaming information $\mathrm{m}$ any format that an agency can reasonably provide. The affirmative dissemination obligation in [the bill] ends any remaining controversy by einphasizing the importanee of making data available in formats that will be useful to users." Id. at 26 n.25.

250. In the context of electronic records, the Report cited a previous Cominittee recominendation:

A Federal agency's responsibility to provide for public use of agency records sliould not be considered to be fixed or fully satisfied at any point in time. Pubtic access is a dynamic concept. If an agency lias developed the ability to mampulate data electronically, it is unfair to restrict the public to paper documents. ...

... [A] Federal agency should use modern teclinology to improve the range and the quality of public access to agency records. As technology permits an agency to upgrade its own ability to access, copy, and manipulate data, an agency should make reasonable attempts to allow public users of agency information to sliare the benefits of automation.

Id. at 44 (quoting House COMM. ON GOVERNMENT OPERATIONS, EleCTronic COlleCtion AND Dissemination of INFORMation by Federal Agencies: A Policy OVERVIEW, H.R. ReP. No. 560, 99tli Cong., 2d Sess. 10, 11 (1986)). Furthermore, the Coinmittee stated that "[r]eleasing information in electronic formats allows the data to be used more effeetively and by more people." Id. 
treatment of electronic requests under the FOIA. At the very least, these policies niay influence courts that review an agency's denial of a request for electronic agency records. However, in the absence of an express amendment to the FOIA, agencies are essentially free to apply their own policies, which will likely curtail access and promote unnecessary hitigation.

\section{B. Shifting FOIA Administrative Guidance from the DOJ to the OMB}

Title II of the bill, entitled "Federal Government Information Technology," contains a provision that would amend the FOIA ${ }^{251}$ by striking the sentence in the FOIA that requires that the annual FOIA report submitted by the DOJ to "include a description of the efforts undertaken by the Department of Justice to encourage agency compliance with [tlie FOIA]."252 Instead, the bill shifts the administrative oversight function to the OMB.

The Committee Report explaims that the DOJ liad previously issued administrative guidance over the FOIA based on miplied authority. ${ }^{253}$ In the 1986 FOIA amendments, however, "Congress assigned OMB the responsibility to promulgate guidelines providing for a uniform scliedule of fees."254 Thus, witl botli the OMB and the DOJ issuing guidance over tlie FOIA, a conflict lias arisen, leading to "confusion and excessive bureaucracy in the FOIA administrative process."25s The Report states that Congress deliberately did not assign guidance over the FOIA to the DOJ in the 1986 FOIA amendments and that the bill's amendment completes the shift of the guidance function to the OMB. ${ }^{256}$

In addition to the benefits of centralizing FOIA guidance in one agency, the Report provides another reason for removing the DOJ's authority to encourage agency coinpliance with the FOIA: the elimination of "an inherent conflict of interest that arises from the Department's hitigation responsibilities under the FOIA."257 Because the DOJ represents all agencies in FOIA litigation, and that the goal of litigators is to win cases, the DOJ could not be expected to provide neutral and unbiased

251. Paperwork Reduction and Federal Information Resources Management Act, H.R. 3695, 101 st Cong., 2d Sess. § 204(b)(1), 136 CoNG. REc. 11,901 (daily ed. Oct. 23, 1990).

252. 5 U.S.C. $\$ 552(\mathrm{e})(1988)$.

253. H.R. REP. No. 927 , supra note 246 , at 65 .

254. Id. (citmg 5 U.S.C. § 552(a)(4)(A)(i) (1988)).

255. Id.

256. Id. The Commission believes that centralizing all FOIA guidance at the OMB will simplify agency use of the FOIA.

257. Id. See generally H.R. REP. No. 1419, 92d Cong., 2d Sess. $65-66$ (1972) (noting the DOJ's "triple role" as agency, government litigator, and FOIA advisor). 
guidance. ${ }^{258}$ Thus, the Committee believes that the FOIA would operate best if all admimistrative guidance was controlled by a single agency, but not the DOJ.259

It is difficult to predict whether reinoving FOIA guidance froin the DOJ would increase public access to government information. Although the DOJ could never coinpel agencies to implement its guidelines, ${ }^{260}$ the conflict of interest alluded to by the Committee probably lias an imdirect impact on access to the extent that agencies incorporate DOJ guidelines and policies in their day-to-day FOIA operations. Although entrusting FOIA oversight to the OMB may eliminate soine conflicts of interest, some tension would still remain; the OMB is still an agency that is itself subject to the burdens of the FOIA.

\section{Conclusion}

For the inost part, FOIA developments in 1990 are not promising for the American public. Altlough the New York Times decision was the most interesting of 1990, in all probability the effect of its inpact on disclosure will be minimal because only tle non-lexical information with privacy implications will be lield exempt. By far the most serious threat to the "freedom of information" is categorical decisionmaking. Even assuming, arguendo, that the Supreme Court did authorize such an approacl, it is a liarmful (and activist) method by which courts could potentially create, on a case-by-case basis, a lengthy hist of judicial FOIA exeinptions. This alone necessitates a congressional response-preferably an ainendinent to the FOIA that provides that courts must consider the facts of eacli case im their disclosure determination.

Similarly, tlie Supreme Court's public interest requirement could potentially become a standard requirement for all FOIA requests, creating an inconsistency in whicl some courts are more willing than others to accept a plaintiff's opportunistically asserted interest in knowing what the government is up to. At a minimum, the requirement would seriously undermine the efforts of many historians and similar researchers.

Finally, altliouglı congressional committee opinions may resolve electromic FOIA issues for soine federal agencies, tliey are not mandates. In the absence of an explicit statutory policy, agencies are free to imple-

258. H.R. REP. No. 927, supra note 246 , at $65-66$.

259. Id. at 66.

260. See generally H.R. REP. No. 1419, supra note 257, at 66 (quoting testimony of Assistant Attorney General Ralph E. Erikson: "[The DOJ] generally [has] no authority to compel another agency to comply with a request for its records. Subject to this limitation, the functions of the Justice Department in [FOIA] matters are [limited to] counseling, coordmating, and representing other agencies in court."). 
ment their own policies to the detriment of the public. In short, the FOIA is due for another amending session. 


\section{,}

